Steven Franks

Indiana University-Bloomington

\title{
Orphans, Doubling, Coordination, and Phases: On Nominal Structure in Slovenian*
}

This contribution examines the Orphan Accusative (OA) construction found in Slovenian with the aim of understanding its unique properties within an articulated model of noun phrase structure.

Članek analizira navezovalni tožilnik v slovenščini z namenom, da bi razložil njegove posebnosti v podrobno razdelanem modelu strukture samostalniške zveze.

\section{Introduction}

The Orphan Accusative (OA) construction has long fascinated linguists. In their comprehensive study of the OA, Perlmutter and Orešnik (1973) not only laid out the core facts and issues, but also identified several factors likely to play a role in any successful analysis. At that time, however, the role of functional categories in extending lexical projections such as noun $(\mathrm{N})$ beyond the NP was not properly understood. Moreover, their heavily transformational account invoked a derivational scenario that has long since been superseded by more transparent mechanisms. So my initial task in this paper is to update the account of Perlmutter and Orešnik (henceforth, P\&O) and see what insights emerge. In doing so I follow recent arguments by Bošković (e.g., 2005, 2008, 2009), Despić (2013), and others who state that one can associate a host of typological differences between languages where nominals canonically culminate in NPs and those where NPs are contained within a higher functional projection such as a determiner phrase (DP). In this light, I then consider how the OA facts - and the structures needed to understand them-might bear on the debate over where Slovenian fits in. I argue that Slovenian has a silent pronominal (a pro $o_{\mathrm{N}}$ ) which, given P\&O's Accusative Prediction Rule (APR), behaves as if animate. I further suggest

* This paper recapitulates discussion of the Orphan Accusative in Franks (in press) and attempts to connect it to larger questions of the status of DP in Slovenian. I am indebted to the 2009 conference presentations on the OA by Gilbert Rappaport and Anita Peti-Stantić. I thank both of these scholars for sharing their ideas and materials with me, as well as Lanko Marušič, Rok Žaucer, Tatjana Marvin, Don Reindl, Petra Mišmaš, and especially Peter Jurgec for help with the Slovenian OA data. I am also grateful to two Slovenski jezik reviewers for their helpful comments. 
that the OA phenomenon depends on the additional structure afforded by the DP type, indicating that Slovenian may well be developing into a DP language. All the above belongs to section 2, which constitutes the bulk of the paper and which culminates in section 2.4 .2 with a sketch of where Slovenian fits into the larger picture (in South Slavic and more generally). In the remainder, I turn to other potentially relevant diagnostics, attempting to push the idea that there is functional material above NP in Slovenian to see where it leads. The speculative discussion in sections 3 and 4, respectively, suggests that clitic doubling in dialects (as described by Marušič and Žaucer 2009) requires some version of DP, as does so-called distant first conjunct agreement. Section 5 notes some possible problems, and section 6 offers some reflections about how the APR and animacy might be formally implemented.

\section{The Orphan Accusative}

As (1) and (2) show, and as seen in other languages, Slovenian verbs ordinarily take accusative direct objects. However, when the object noun is missing, the adjective unexpectedly appears in the genitive if the noun is masculine, as in (3a). Curiously, when the missing noun is feminine, as in (3b), only the normal accusative form is possible: ${ }^{1}$

(1) a. Kateri acc $_{\text {kruh }}$ acc hočete?

b. Hočem beli acc $_{\text {kruh }}$ acc.

'Which bread do you want?'

'I want the white bread.'

(2) a. Katero ${ }_{\text {acc }}$ hišo ${ }_{\text {acc }}$ hočete?

'Which house do you want?'

b. Hočem novo ${ }_{\text {acc }}$ hišo ${ }_{\text {acc }}$.

'I want the new house.'

(3) a. Hočem belega $a_{\text {gen }} /{ }^{*}$ beli $_{\text {acc }}$.

'I want the white one'.

b. Hočem * nove gen $/$ novo $_{\text {acc }}$.

'I want the new one'.

This peculiar use of the genitive form in canonical accusative contexts such as (3a) is traditionally referred to as navezovalni tožilnik or navezovalna končnica and was dubbed the "Orphan Accusative" by P\&O.

The OA is not restricted to post-verbal position, but applies in any accusative position. In (4) we see the OA after prepositions that govern the accusative:

${ }^{1}$ An anonymous reviewer suggests that the genitive would only be acceptable in (3a) if the verb were negated, and elsewhere implies that the orphaned adjective can only be genitive if the missing noun is animate. While in this paper I use affirmative examples to abstract away from the interfering phenomenon of the genitive of negation, as in (8a), and take pains to explain the central role of animacy in my eventual analysis, it is clear that this reviewer simply does not admit the OA construction in general. Whether this reflects dialectal variation or the imposition of normative values I do not know, nor am I able to address issues of colloquial versus literary language. Finally, I report examples drawn from the OA literature faithfully, and without concern for prescriptivist desiderata. 
(4) a. Za katerega $\mathbf{g e n} /$ kateri $_{\text {acc }}$ si se odločila: za belega $\mathbf{a g n}_{\text {gen }} / *$ beli $_{\text {acc }}$ ali za modrega $_{\text {gen }} / *$ modri ${ }_{\text {acc }}$ ?

'Which one did you pick: the white one or a blue one?'

b. princip, v katerega $\mathbf{g e n}_{\text {gen }} /$ kateri $_{\text {acc }}$ verjamem ...

'the principle in which I believe ...'

On the other hand, the OA never applies when the missing noun is feminine, or if it is dual or plural. Interestingly, when the missing noun is neuter the OA can apply, although with some vacillation and speaker uncertainty. P\&O state that both are possible in the example reproduced in (5a), while Rappaport (2009) cites $(5 \mathrm{~b}, \mathrm{c}):^{2}$

(5) a. Katero ${ }_{\text {acc }}$ proso $_{\text {acc }}$ hočete? Navadnega $a_{\text {gen }} /$ navadno $_{\text {acc. }}$. 'Which millet do you want? Ordinary.'

b. . . določilo, ki je spolni odnos med dvema moškima obravnaval kot kaznivo dejanje, za katerega $a_{\text {gen }}$ je bila predvidena zaporna kazen od enega do petih let, ... '. . . the amendment that treated sexual relations between two men as a criminal act for which a prison sentence from one to five years is provided, . . ' (ISZ ZRC SAZU corpus)

c. Se zaveda življenja, kakršnega ${ }_{\text {gen }}$ Živi. $^{3}$

'(He) is conscious of the (kind of) life which (he is) leading.' (Toporišič 2004)

These are the basic facts.

\subsection{Orphan Accusative Puzzles}

This phenomenon immediately raises a host of issues. The questions posed by $\mathrm{P} \& \mathrm{O}$ $(1973,422)$ about the OA and repeated below are exactly what one should ask:

(6) Perlmutter and Orešnik's questions about the Orphan Accusative

1. Why is it that the special form found in the OA is not just an arbitrary ending?

2. Why is the OA form the same as that of the genitive case?

3. Why do all constituents with adjectival endings, rather than just quantifiers or demonstratives or just adjectives that refer to transient properties, have a special form for the OA?

4. Why is it that masculines have a special OA form and feminines do not?

5. Why is it that the accusative has a special form, rather than some other case?

\footnotetext{
${ }^{2}$ Unless otherwise indicated, I have retained translations from the indicated source.

${ }^{3}$ An anonymous reviewer suggests that kakršnega is genitive because the matrix verb se zaveda governs the genitive (as expressed on its object življenja); relative pronouns, however, receive their case within their own clause, not through agreement.
} 
6. Why is there a special form in the absence of the head noun, and not some other environment?

7. Why Slovenian-what is particular to Slovenian in the OA phenomenon, and what is more general?

$\mathrm{P} \& \mathrm{O}$ set out to address these questions and, to no mean degree, succeed in making sense of them. It is nonetheless worth adding to this list of questions new ones that situate the issue within a more contemporary framework, in the hope of leading to new ways of understanding the Slovenian OA. In particular, we now have available a more explicit theory of phrase structure as well as a more explicit conception of types of "missing" material. This should enable us to approach P\&O's questions from a fresh perspective.

The leading question is the P\&O's second one, namely, Why the genitive? Any answer to this must be driven by solutions to the following more general questions:

(7) a. What is the internal structure of the extended nominal projection in Slovenian?

b. What is the nature of the "missing" nominal part?

Question (7a) asks what projections one should posit above NP for Slovenian. While the vast amount of research into extended nominal projections over the past few decades has established the need for functional projections above NP, there is also considerable variation across grammars. So, for example, case features and specificity features can be instantiated not just on NP, but also on a distinct kase phrase (KP) and/or a distinct DP; the names of the functional categories are not as important as their independent existence and their specific properties. Question (7b) depends naturally on (7a), asking how the OA should then be analyzed. A variety of mechanisms exist to render material interpretable to Logical Form (LF) silent on the Phonetic Form (PF) side. In particular, we can wonder at what point in the derivation the adjectival material is "orphaned": Is the missing nominal material elided in the course of the derivation or is it silent pro from the start (and, if so, what are the categorical and other properties of this pro)? I will argue that the OA instantiates agreement with a pro $_{\mathrm{N}}{ }^{4}$

Finally, if the reason why the form of the orphaned adjective is genitive(-like) must be the leading question, then P\&O's last question of how Slovenian is different must be the closing one. Whatever our answers to (7) turn out to be, the reason Slovenian is special will surely be a consequence of those answers. I will also examine how other languages - specifically, other South Slavic languages, since they are minimally distinct from Slovenian-differ so that the answers to (7) for Slovenian do not accidentally implicate them as well.

\footnotetext{
${ }^{4}$ However, Slovenian also countenances nominal ellipsis - a fact which obfuscates the data since simple ellipsis does not introduce any agreement complexities.
} 


\subsection{The Nature of the Solution}

The OA should be understood as parasitic on some more general case phenomenon. In particular, it should exploit some more familiar alternation between accusative and genitive direct objects. These alternations are of two well-established types in Slovenian. First, there are situations, as in other Slavic languages, where an expected accusative case context is converted into a genitive context. For example, in Slovenian the genitive is assigned instead of accusative under negation (8a) or quantification (8b):

(8) a. Nisem bral zanimive gnen $_{\text {kjige }} / *_{\text {gen }}$ zanimivo $_{\text {acc }}$ knjigo $_{\text {acc }}$

'I did not read the interesting book.'

b. Prebral sem pet zanimivih gen $_{\text {knig }} / *_{\text {gen }}$ zanimive $_{\text {acc }}$ knige $_{\text {acc }}$. 'I read five interesting books.'

Here, despite the existence of an accusative form, the genitive case must be used because of the negative $n i$ or the numeral pet; this is a semantically sensitive replacement of syntactic accusative by genitive. The OA on the other hand has no semantic import; ${ }^{5}$ it is thus the second type of alternation that is relevant to the OA. This is when a genitive morphological form is employed in accusative contexts. Some examples are given below: ${ }^{6}$

(9) a. Predstavljam vam našo ${ }_{\text {acc }}$ prijateljico $_{\text {acc }}$.

'Let me introduce to you our (female) friend.'

b. Predstavljam vam našega $a_{\text {acc/gen }}$ prijatelja $_{\text {acc/gen }}$.

'Let me introduce to you our (male) friend.'

c. Predstavljam vam našega ${ }_{\text {acc/gen }}$ vodjo $_{\text {acc }}{ }^{7}$

'Let me introduce to you our (male) leader.'

\footnotetext{
${ }^{5}$ Peti-Stantić (2009) does however attempt to build an argument that semantics should be implicated in the OA; see Franks (in press) for discussion of her claims.

${ }^{6}$ In the examples in (9) and elsewhere, the first case indicated is what is syntactically governed (always accusative), while the second is the form that is actually employed (either nominative or genitive, depending on the rule in (10)).

${ }^{7}$ Note that both the declensionally faithful $-o$ and an innovative vodja are possible, the latter based on a consonantal masculine stem. I thank Rok Žaucer and Don Reindl for discussion of this type of example. Reindl (p.c.) cites Herrity's $(2000,52)$ comment that such nouns "tend to favour masculine forms in some cases and feminine forms in others . . Imamo dobrega računovodjo 'We have a good accountant' [feminine -o] . . . s tem računovodjem 'with this accountant' [masculine -em]'." A google search reveals both našega kolego and (many more) našega kolega. Žaucer (p.c.) points out that preferences depend on the lexical item, and Herrity says the same. Reindl adds that prescriptively, "the -ega -o pattern is also blessed by the normative guide (Slovenski pravopis 2001, p. 93)." The relevant point, however, is the consistent behavior of the adjective in reflecting animacy.
} 
These direct objects are accusative, as demonstrated by (9a). In (9b) and (9c), however, a genitive form occurs.

Significantly, whereas in (8) the entire NP complement appears in the genitive case, here the genitive form appears even though the accusative is called for syntactically. In (9c) we even have a mixed phrase with a genitive suffix on the modifier, even though the noun is unambiguously accusative. In what follows I will argue that the Slovenian OA similarly resorts to the genitive morphological form in accusative syntactic contexts.

\subsubsection{The Accusative Prediction Rule}

The accusative pattern in (9) tracks animacy. We might consequently add (9d), with an inanimate object:

(9) d. Predstavljam vam naš $\check{a c c}_{\text {anom }} \operatorname{grad}_{\text {acc/nom. }}$ 'Let me introduce to you our city.'

We are thus dealing with a more general morphological rule, traditionally known as the Accusative Prediction Rule (APR). P\&O's version is given below:

(10) Accusative Prediction Rule

a. For animates, the accusative is like the genitive.

b. For inanimates, the accusative is like the nominative.

The APR does not apply if the paradigm has a distinctly accusative form; hence, it is irrelevant in (9a). It is thus an instruction about where to look when the morphological system provides no accusative entry. The phenomenon thus reflects a paradigmatic rather than syntagmatic solution, whereby animate (and certain other; cf. Herrity 2000, 34) masculine singular nouns employ the morphological genitive in accusative contexts.

Crucially, the APR also extends to how adjectives agree. We thus find the genitive form našega in $(9 \mathrm{~b}, \mathrm{c})$ because the nouns are animate, and the nominative form $n a s ̌$ in (9d) because the noun is inanimate. P\&O's account correctly capitalized on this fact by coupling it with the observation in (11):

(11) Pronouns in Slovenian behave morphologically as if they were animate.

In particular, the Slovenian masculine accusative clitic pronoun $g a$, although technically genitive-like in form, is able to refer to an inanimate masculine (or neuter) noun. $\mathrm{P} \& \mathrm{O}$ then implement the insight that the OA manages to exploit the APR as follows:

(12) a. The noun is replaced by an appropriate pronoun.

b. Concord takes place between the modifiers and the pronoun.

c. The pronoun is deleted, orphaning the modifiers. 
Theirs was a highly derivational system, with each rule feeding the next one. Since pronouns are animate, the result of (12a) is that concord in (12b) will induce the genitive form on agreeing modifiers. This only happens, however, when the pronoun is $g a$. The reason is that $g a$ is the only form in the Slovenian pronominal clitic paradigm where (11) actually matters. All other pronominal paradigms have a distinct accusative form; hence, the APR is elsewhere simply not invoked. Because $g a$ is the masculine singular form, this is where (10) can apply, giving rise to the OA.

\subsubsection{Identity of Sense}

It will be noted that, by directly addressing question (6.2) above-Why is the OA form the same as that of the genitive case? - the previous account comes neatly to grips with all the other questions posed by $\mathrm{P} \& \mathrm{O}$ except for the last one: Why is the OA limited to Slovenian? However, coopting the genitive form appropriate for animates to inanimate accusative pronominals is a more general Slavic phenomenon, one which operates whenever the paradigm is missing a distinct accusative form. In order to single out Slovenian, therefore, something more than (11) must be relevant. Why is it that (10a) — which pertains to other Slavic languages - overapplies just in Slovenian by mapping adjectives which modify missing inanimate nouns into the genitive rather than the expected accusative form?

In this context, $\mathrm{P} \& \mathrm{O}$ observe that, in addition to (11), the interpretation of Slovenian pronouns is special:

(13) Slovenian pronouns allow an Identity of Sense interpretation, not just the standard Identity of Reference.

Pronouns are ordinarily interpreted as coreferential with referring expressions in the sentence or discourse, that is, they express specific tokens. This "strict" reading is what $\mathrm{P} \& \mathrm{O}$ call Identity of Reference (I/R). In Slovenian, however, clitic pronouns are also able to refer back to the unindividuated properties of the antecedent, that is, they can also express the general type. This "sloppy" reading is what P\&O call Identity of Sense (I/S). This distinction is comparable to the difference between it and one in English, where the former evokes I/R, the latter I/S. In most languages, pronouns must be referential, as shown by the Slavic examples in (14): ${ }^{8}$

${ }^{8}$ I thank M. Shardakova and M. Shrager, M. Mullek and P. Kosta, and R. Slabakova and R. Pančeva for these Russian, Slovak, and Bulgarian judgments, respectively. For Russian (14a) I provide masculine (indeclinable) avto as well as feminine mašinu, with masculine/ neuter pronoun ego or feminine ee, respectively; for Slovak (14b) I provide neuter auto as well as masculine automobil, with pronominal clitic ho able to refer back to either; Bulgarian (14c) just shows masculine automobil, with pronominal clitic go. Incidentally, I chose 'car' for these and other examples simply to keep them close to P\&O's original (and because I wanted to vary the gender independently of the semantics). An anonymous reviewer however cautions me that cars in Slavic (inter alia) tend to anthropomorphize hence may actually be interpreted as 
(14) a. Vanja videl sinij avto/sinjuju mašinu i Petja tože ego/ee videl. [Russian] 'Vanya saw a blue car and Pete also saw it/*one.'

b. Pavol videl modré auto/modrý automobil i Peter ho tiež videl. [Slovak] 'Pavol saw a blue car and Peter also saw it/*one.'

c. Ivan vidja sin automobil i Petâr go vidja sâšto. 'Ivan saw a blue car and Peter also saw it/*one.'

[Bulgarian]

In Slovenian, however, clitic pronouns need not be referential, denoting instead the unindividuated properties of the antecedent. That is, they can also express the general $\mathrm{I} / \mathrm{S}$ type, as shown by the data set in (15) from $\mathrm{P} \& \mathrm{O}$ :

(15) a. Stane je videl plav avto in tudi Tone ga je videl. 'Stane saw a blue car and Tone also saw it/one.'

b. Stane ima rjav površnik in tudi Tone ga ima. 'Stane has a brown overcoat and Tone also has one.'

c. Stane ima pametnega otroka in tudi Tone ga ima. 'Stane has a smart child and Tone also has one.'

d. Stane ima pametno ženo in tudi Tone jo ima. 'Stane has a smart wife and Tone also has one.'

As the translations indicate, the I/S interpretation corresponds to English one, whereas only the I/R it interpretation is available in the parallel Russian, Slovak, and Bulgarian examples. Slovenian thus seems typologically striking in that pronouns in related languages lack the I/S interpretation. ${ }^{9}$ My eventual analysis of the OA will capitalize on this point.

\subsubsection{One and the Complement-Adjunct Asymmetry}

Consider first how English one receives an I/S interpretation. The traditional account regarded one as smaller than a full NP and bigger than an N; it was arguably a pro-N', that is, substituting for what was then analyzed as N':

(16) a. I like [ ${ }_{\mathrm{NP}}$ this $\left[{ }_{\mathrm{N}}\right.$ student from France]] better than that one [=student] from Italy.

b. *I like $\left[{ }_{N P}\right.$ this $\left[{ }_{N},\left[_{\mathrm{N}}\right.\right.$ student $]$ of chemistry $]$ better than that one [=student] of physics.

animate. General overapplication of the animacy rule is another avenue to explore, and indeed Peti-Stantić (2009) considers this factor, noting that Slovenian does not apply the animacy rule as restrictively as some other languages (cf. Herrity 2000, 34).

${ }^{9}$ Runić (2013b) however argues that I/S is generally available in NP languages, including Czech, Slovak, and especially Bosnian/Croatian/Serbian (BCS). I return to BCS in more detail in Section 2.4.1. 
c. I like [ ${ }_{\mathrm{NP}}$ this [ ${ }_{\mathrm{N}}$ student of chemistry]] better than that one [=student of chemistry].

d. I like $\left[\mathrm{NP}_{\mathrm{N}}\right.$ this $\left[{ }_{\mathrm{N}}\right.$, student of chemistry] from France] better than that one [=student of chemistry] from Italy.

Crucially, one substitution necessarily replaces the noun plus its complements. Thus, not only is (16a) acceptable because from France is an adjunct, but (16c, d) are also acceptable with one substituting for student of chemistry. However, complements, as shown by (16b), cannot be excluded. Finally, adjuncts can also (but need not) be included:

(16) e. I like [ ${ }_{\mathrm{NP}}$ this $\left[{ }_{\mathrm{N}}\right.$ student from France] better than that one [=student from France].

More recent models of phrase structure argue for a DP above NP. By recasting in this light (16) as (17), we see that one might more accurately be understood as a pro-NP:

(17) a. I like [DP this [NP student from France]] better than that one from Italy.

b. *I like [DP this [NP' [N student] of chemistry]] better than that one of physics.

c. I like [DP this [ ${ }_{\mathrm{NP}}$ student of chemistry]] better than that one.

d. I like [ ${ }_{\mathrm{DP}}$ this [ ${ }_{\mathrm{NP}}$ student of chemistry from France]] better than that one from Italy.

e. I like [DP this [NP student from France]] better than that one.

While this move explains why the D element this is never included in the pro element's reference, the (a) and (d) examples remain problematic. Calling one a pro-NP does not seem to allow one in (17a) to target student, which is smaller than the entire NP; a similar situation occurs in (17d), where one refers back to student of chemistry. The correct observation is that the pro-form one substitutes for a head noun plus its complement obligatorily, and any adjuncts optionally.

This fact readily falls out from Chomsky's (1995) Bare Phrase Structure (BPS) system. Minimalism eschews X' as a syntactically accessible node. Intermediate projections are not primitives: there is no such thing as N', hence no pro-form could refer to it. X-bar status is instead relationally defined as something which is neither a head/ $\mathrm{X}^{0}$ (=a category which does not project at all) nor a phrase/XP ( $=$ a category which does not project any further). In this system, lexical items drive the derivation. Trees are built from the bottom up by selecting an item from the inventory of lexical resources known as the "Numeration," "10 and then merging it with some other element to result in a binary branching structure. If Merge of YP takes place to satisfy the lexical needs of the head $\mathrm{X}$, then the $\mathrm{YP}$ is an argument of $\mathrm{X}$, and $\mathrm{X}$ projects (with one fewer lexical requirement in need of saturation); otherwise $\mathrm{YP}$ is an adjunct to $\mathrm{X}$ (the projection of which remaining identical).

${ }^{10}$ More precisely, the Numeration is relevant for Initial Merge (aka External Merge), the tree is for (Re)merge (aka Internal Merge, i.e., movement). Another workspace is needed for "sidewards" movement as well as for merging complex heads or specifiers. 
Imagine that a noun has been selected and merged with phrasal (non-projecting or maximal) material (which as noted in fn. 10 would already have been constructed in a separate work space but according to the same principles) and the N projects. Eventually, when the projection of $\mathrm{N}$ combines with another head X, then that head X projects instead. Consider the very nice student of physics from France in (18). Note that only lexical categories are represented in (18); the superscript (max) is intended merely as a typographic device to help identify maximal projections. Crucially, it is not possible to determine in the course of the derivation whether any particular node $\mathrm{X}$ is maximal or not until something else merges with it. This point will be essential in understanding the workings of English one and its Slovenian counterpart pro $_{\mathrm{N}}$.

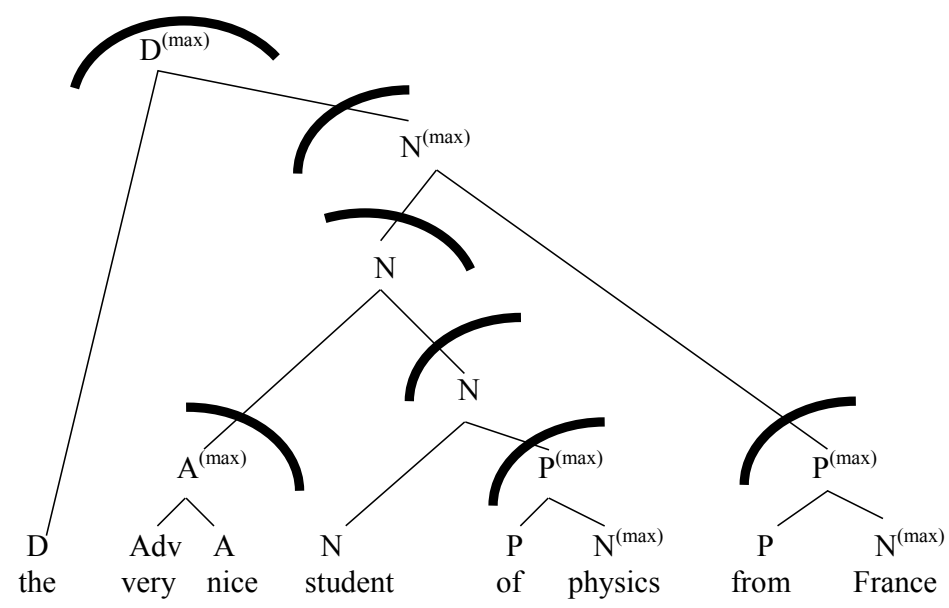

In building (18), successive applications of Merge must combine two nodes into one, projecting the head; here I have set off every merged pair of nodes to facilitate identification. Note that the relative scope of the AP very nice and the PP from France could be different, with very nice merging after from France rather than before, but because these are adjuncts, the order in which they combine (and thus their relative scope) is technically free. ${ }^{11}$ Crucially, the same is not true of the complement of physics, which is an argument of student. When an adjunct merges with $\mathrm{X}$, its meaning composes with that of $\mathrm{X}$ in a purely compositional manner. However, when a complement merges with $\mathrm{X}$, the resultant meaning is a function of the argument structure of $X$.

${ }^{11}$ That is, the linear order in (18) could mean 'the student of physics who is very nice from France' (answering Which very nice student of physics?), as depicted, or 'the student of physics from France who is very nice' (answering Which student of physics from France?). 
Within the BPS context, a straightforward account of one substitution presents itself. Following Franks (1999), the "pro-noun" one is just that, a noun. As a noun, it receives its sense from its antecedent-crucially, I/S not I/R. This antecedent can be any available node of category N. Consider (19), in which one can substitute for any projection of N. Since the nominal projections dog, black dog, and big black dog are formally indistinguishable, all being $\mathrm{N}$, one (which is also an N) can mean just 'dog', 'black dog' or 'big black dog':

(19) Jane kissed $\left[_{D}\right.$ this $\left[{ }_{N}\right.$ big $\left[{ }_{N}\right.$ black $\left[{ }_{N}\right.$ dog $\left.\left.\left.]\right]\right]\right]$ and Jean kissed that one.

However, as an $\mathrm{N}$ rather than a $\mathrm{D}$, one has no referential features. So what it cannot refer back to in (19) is this big black dog. This is what differentiates the pronoun one from words like $i t$, he, or she, which lead to I/R. Traditional pro-nouns are of course really pro-Ds, that is, they substitute full, referential DPs. Compare one and it in (20):

(20) a. Jane kissed [D Fred's $\left[_{\mathrm{N}}\right.$ big $\left[_{\mathrm{N}}\right.$ black $\left[_{\mathrm{N}}\right.$ dog $\left.\left.\left.]\right]\right]\right]$ and Jean kissed one too.

b. Jane kissed [ ${ }_{\mathrm{D}}$ Fred's big black dog] and Jean kissed it too.

Furthermore, any semantically appropriate $\mathrm{N}$ in the discourse is accessible. That this is not a matter of syntactic anaphora is demonstrated by the examples in (21). The accessibility of the Ns economics textbook and anthropology books show that formal structural relations such as c-command are irrelevant:

(21) a. A: $\left[{ }_{\mathrm{D}}\right.$ Which $\left[_{\mathrm{N}}\right.$ economics $\left[{ }_{\mathrm{N}}\right.$ textbook $\left.]\right]$ did David end up buying?

B: The one by Mankiw.

b. Elisabeth decided to read $\left[_{D}\right.$ the $\left[_{N}\right.$ dust jackets of $\left[_{D}\right.$ the library's $\left[_{N}\right.$ dull ${ }_{\mathrm{N}}$ anthropology books]]]]], after realizing that all the interesting ones had already been checked out.

Finally, and most importantly, as a pro-form one can have no theta-roles of its own to assign. This is why, as argued in Franks (1999), one never takes a complement: if it did, then that complement would have no way to receive a theta-role, hence it could not be interpreted. ${ }^{12}$ As an $\mathrm{N}$, one can merge with any adjunct to create a higher $\mathrm{N}$ projection, but it can never merge with a complement. This is an essential property of all pro-forms:

(22) John will bake a pie and Mary will (bake/*do (so)) a cake. ${ }^{13}$

${ }^{12}$ Panagiotidis (2003a) offers roughly the same account of English one as in Franks (1999); see also Panagiotidis (2003b).

${ }^{13}$ Although ellipsis of bake is indicated here by outline font, this may not be the correct account of gapping, since (22) could involve movement of a cake out of the VP, with 
A pro-form lacks a thematic grid; it is exclusively identifiable by virtue of its discourse antecedent. English one is thus unable to take a complement of any kind, although it is free to combine with adjuncts. While this distinction is not always clear cut, and nouns are reluctant to take true complements, judgments about one generally reflect this asymmetry between complements and adjuncts. For example, nouns such as claim and decision may take a propositional complement or be modified by a relative clause, both beginning with the word that, but only the latter can interact with one substitution. We can thus use it as a test to distinguish complement clauses, which are typically degraded, from relative clauses, which are invariably fine:

(23) a. ?*David's claim that the world is flat is not as strange as Elisabeth's one that 65 million years ago aliens took all the dinosaurs to another planet.

b. David's claim (that) you rejected was not as strange as Elisabeth's one (that) you accepted.

(24) a. ?*The decision that we must leave was less surprising than the one that we must stay.

b. The decision (that) David made was less surprising than the one (that) Elisa beth made.

\subsection{Back to Slovenian}

We return to the Slovenian OA in this light. In this section I will argue that the Slovenian lexicon countenances a phonetically silent counterpart of English one, that is, it has a silent pronoun which I represent pro $_{\mathrm{N}}$, the sense of which, just like one, is determined through matching with an overt $\mathrm{N}$ established in the discourse.

\subsubsection{Some Additional Data}

To review, here are some additional representative examples from the literature to illustrate the extent of the OA phenomenon. First, in a sequence of adjectives modifying a missing noun, all of them go into the OA:

(25) a. Moji sosedi imajo dva avta, enega $a_{g e n}$ rdečega $_{\text {gen }}$ in enega $\mathbf{a}_{\text {gen }}$ zelenega $_{\text {gen }}$. (Herrity 2000)

'My neighbors have two cars, a red one and a green one.'

b. Ima samo enega $\mathbf{g}_{\mathrm{gen}} \mathbf{s t a r e g a}_{\mathrm{gen}} \mathbf{r j a v e g a}_{\mathrm{gen}}$.

'He has only one old brown one.' (P\&O)

subsequent deletion of the entire VP. The point nonetheless remains that the pro-form do cannot assign the theme theta-role of bake. 
Note also that appositive adjectives go into the OA:

(26) a. Mlada žena zahtevala, naj ji prodajo parfum, prav tistega $a_{\text {gen }}$, ki je v izložbi. (Rappaport 2009)

'The young woman wanted them to sell her perfume, precisely that one in the display window.'

b. Se en prizor si je zamislil, najprisrčnejšega $a_{g e n}$, najneizraznejšega $a_{g e n}$. (Rappaport 2009)

'It's quite a spectacle you've made up, a most hearty, a most distinctive one.'

c. Videl sem velik zemljevid, obsegajoč hrvatski okraj, in majhnega $\mathbf{g e n}_{\text {gen }}$ obsegajočega $_{\text {gen }}$ slovenski okraj.

'I saw a large map, comprising a Croatian district, and a small one, comprising a Slovene district.' (P\&O)

P\&O's (26c) combines a canonical missing nominal example, in majhnega [zemljevid 'map' $\rightarrow g a \rightarrow \varnothing]$ 'and a small one', with an appositive participle, obsegajočega 'comprising', which itself takes a nominal complement.

\subsubsection{The Orphan Accusative is a pro $_{\mathrm{N}}$}

We are now in a position to put all the parts of the OA puzzle together. As stated, what is special about Slovenian is that it has a silent version of English one, namely, pro $_{\mathrm{N}}$. As a pronoun, and in accordance with (11), pro $o_{\mathrm{N}}$ bears the morphological feature [+animate]. And because this lexical item is available, it can be selected and merged (optionally) with adjuncts until another head is selected to merge with it. Whenever those adjuncts are adjectival, they undergo concord with pro $_{\mathrm{N}}$, giving rise to the OA. My account is thus essentially a modernizing of P\&O's original system in (12), but without the transformational trappings:

(27) A silent pronoun pro $_{\mathrm{N}}$ is merged and modifiers agree with it accordingly.

Modifiers look genitive whenever the APR rule in (10a) is invoked. To illustrate, consider (28) from this perspective.

(28) Stane ima star rjav površnik, Tone pa ima novega. (based on P\&O)

'Stane has an old brown overcoat, and Tone has a new (brown) one.'

In (28), pro $_{\mathrm{N}}$ can either have the sense površnik 'overcoat' or rjav površnik 'brown overcoat', since both are realistic antecedents in the discourse context. Relevant structures for the antecedent and the OA component are in (29): 

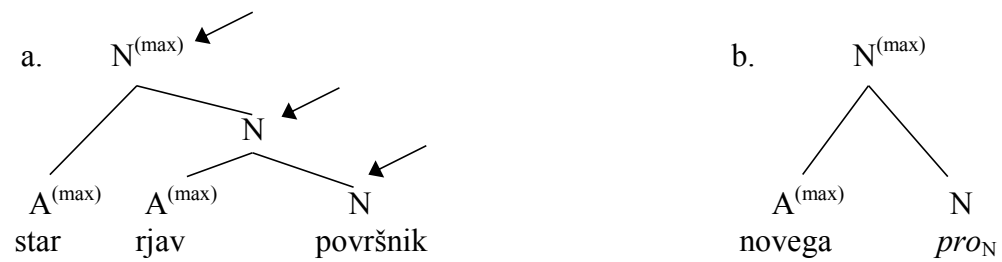

The arrows in (29a) indicate the syntactic range of $\mathrm{N}$ antecedents for pro $_{\mathrm{N}}$, although only površnik and rjav površnik are sensible (new and old being incompatible under most scenarios).

On the other hand, we predict that if pro $_{\mathrm{N}}$ were ever to merge with a phrase that needed to be theta-marked as an argument - or indeed with any element that could not be interpreted as a purely compositional modifier - then the result would be semantically ill formed. ${ }^{14}$ The examples below show that this prediction is indeed borne out. In (30) the antecedent of pro $_{\mathrm{N}}$, tečaj 'course', has a complement fizike '(of) physics', whereas in (31) it does not; additionally, the adjunct na univerzi 'at (the) university' in (31b) is irrelevant to interpreting pro $_{\mathrm{N}}$ :

(30) a. *Peter je naredil tečaj fizike, ampak Janez je naredil enega ${ }_{\mathrm{gen}}$ pro $_{\mathrm{N}}$ matematike. '*Peter passed a physics course, but Janez passed a mathematics one.'

b. *Peter je naredil težek tečaj fizike, ampak Janez je naredil lahkega $a_{\text {gen }}$ pro $_{\mathrm{N}}$ matematike.

'*Peter passed a difficult physics course, but Janez passed an easy mathematics one.'

(31) a. Peter je naredil težek tečaj, ampak Janez je naredil lahkega $a_{\text {gen }}$ pro $_{\mathrm{N}}$. 'Peter passed a difficult course, but Janez passed an easy one.'

b. Peter je naredil težek tečaj na univerzi, ampak Janez je naredil lahkega pro $_{\mathrm{N}}$ na srednji šoli.

'Peter passed a difficult physics course at university, but Janez passed an easy one at school.'

The minimal pair in (32) illustrates the complement versus relative clause contrast, ${ }^{15}$ and the set in (33) illustrates various viable positions for pro $_{\mathrm{N}}$ in more detail:

${ }^{14}$ That is, there is nothing syntactic blocking the OA when it is unacceptable; rather, the problems are interpretative.

${ }^{15}$ This contrast is avowedly subtle after nouns, unlike after verbs. It is hard to force a complement interpretation, so my own judgments about the felicity of one in (32a) vacillate: Does this correspond to "someone proposed that Janez come" or "the proposal = that Janez come"? Factors like introducing a Subject/Agent help cement the complement reading, so that 'I understand Bill's proposal that Janez come and also John's one that he bring beer.' is for me completely unacceptable. 
(32) a. ?*Razumem dober predlog, da bo Janez prišel, in tudi sijajnega $a_{\text {gen }}$ pro $_{\mathrm{N}}$, da bo prinesel pivo.

'?I understand the good proposal that Janez come and also the great one that he bring beer.'

b. Razumem dober predlog, ki ga je Janez imel, in tudi sijajnega $a_{\text {gen }}$ pro $_{\mathrm{N}}$, ki ga je Janez ponovil.

'I understand the good proposal that Janez made and also the great one that Janez repeated.'

(33) a. V sredo bomo zapili Petrov zagovor, in v petek pa Janezovega gen $_{\text {pro }}$.

'We will celebrate Peter's defense on Wednesday and Janez's one [=defense] on Friday.'

b. V sredo bomo zapili Petrov zagovor doktorata, v petek pa Janezovega gen $_{\text {gro }}$. 'We will celebrate Peter's dissertation defense on Wednesday and Janez's one [=dissertation defense] on Friday.'

c. V sredo bomo zapili Petrov zagovor doktorata u veliki dvorani, in v petek pa Janezovega $_{\text {gen }}$ pro $_{\mathrm{N}} \mathrm{u}$ mali dvorani.

'We will celebrate Peter's dissertation defense on Wednesday in the great hall and Janez's one [=dissertation defense] on Friday in the small hall.'

d. Prebrali smo Petrov doktorat, napisan v francoščini, in tudi Janezovega ${ }_{\text {gen }}$ pro $_{\mathrm{N}}$, napisanega $\mathbf{g e n}_{\mathrm{g}} \mathrm{v}$ ruščini.

'We read Peter's dissertation, written in French, and also Janez's one [=dis sertation], written in Russian. ${ }^{16}$

To complete the paradigm, (34) shows that Slovenian pro $_{\mathrm{N}}$ cannot take a complement:

(34) *V sredo bomo zapili Petrov zagovor kriminalcev, v petek pa Janezovega pro $_{\mathrm{N}}$ nedolznezev.

'*On Wednesday we will celebrate Peter's defense of criminals and on Friday Janez's one of innocents.'

${ }^{16}$ Speakers report that the accusative is also acceptable here, although dispreferred:

(i) Prebrali smo Petrov doktorat, napisan v francoščini, in tudi Janezov acc doktorat, napisan $_{\text {acc }} \mathrm{V}$ ruščini.

'We read Peter's dissertation, written in French, and also Janez's, written in Russian.'

In keeping with the present analysis, I treat the accusative possibility as reflecting ellipsis (represented as strikethrough). Further evidence for an account in which Slovenian has two competing ways of deriving such gaps is the fact that the choice of genitive or accusative on the possessive adjective Janezovega/Janezov and on the appositive adjective napisanegal napisan necessarily covaries. 
Just like English one, Slovenian pro $_{\mathrm{N}}$ has no argument structure and so cannot assign a theta-role to the complement nedolznezev 'innocents'. In general, then, the acceptability of the OA parallels the acceptability of English one.

\subsubsection{Some Semantic Restrictions}

I now turn to two possible confounds. The first is based on some data due to PetiStantić (2009). She rejects the animacy account, attempting instead to treat the OA as an "extension of . . . some other semantic category in Slovene." While possible candidates to consider include animacy, definiteness, partitivity, and individuation, there really is no evidence that the Slovenian OA is semantically driven, at least not in the sense Peti-Stantić has in mind. Peti-Stantić eventually argues that the most relevant factor in determining the felicity of the OA is the type of adjective, claiming that "the so called Orphan Accusative occurs as a standard possibility with qualitative and possessive adjectives, but never with relational." While there is some truth to this claim, it is epiphenomenal in that the problem actually derives from the semantically vacuous nature of the missing expression. ${ }^{17}$ All semantic restrictions result from the fact that, as explained above, the OA can only involve adjunct material, and no overt material can be interpreted if it requires access to lexical properties of the missing noun. In short, where pro $_{\mathrm{N}}$ leads to problems of interpretability, the OA becomes infelicitous.

Let us now consider Peti-Stantić's claim and the data sets in (35)-(37) that she provides. Peti-Stantić (2009), following one traditional terminology for types of adjectives, refers to those in (35) as qualitative, in (36) as possessive, and in (37) as relational (classifying), claiming that the accusative is the only possible alternative in (37) because the adjectives are relational: ${ }^{18}$

(35) A: Kupila sem kavč. 'I bought a couch.'

B: Za katerega gen $/$ kateri $_{\text {acc }}$ si se odločila: za belega gen $/ *$ beli acc $_{\text {ali }}$ za modrega $_{\mathrm{gen}} / *$ modri ${ }_{\mathrm{acc}}$ ?

'Which one did you pick: the white one or a blue one?'

${ }^{17}$ A. Giannakidou (p. c.) observes that the more evaluative the adjective, the higher it will be and the more acceptable the OA. Under my account this observation can be turned on its head, in that the more classifying the adjective, the more intrinsic to the noun it will be (hence structurally lower) and the less available the OA.

${ }^{18}$ The traditional definitions are somewhat difficult to pin down. Qualitative adjectives provide information about the qualities of the nouns they modify; they can be graded. Relational adjectives are more commonly referred to as classifying adjectives, which classify the noun by placing it into a class or category; they cannot be graded. Thus the former will not be understood as intrinsic to the noun but the latter may be, as in (37a). This, I argue, is the relevant criterion. While Peti-Stantić identifies a problem for the OA, there is no explanation. My account, on the other hand, offers a well-grounded explanation for why the OA fails with some adjectives traditionally characterized as relational. Gradability might be relevant to the judgments Peti-Stantić reports, except that possessive adjectives pattern with qualitative adjectives with respect to the OA, as in (36), even though not they are not gradable. 
(36) A: Vzela sem dežnik. 'I took an umbrella.'

B: Katerega $\mathrm{gen}_{\mathrm{gn}} /$ Kateri $_{\mathrm{acc}}, \mathbf{m o j e g a}_{\mathrm{gen}} /$ mojacc $_{\mathrm{acc}}$ ali svojega $\mathbf{g e n} /$ svoj $_{\mathrm{acc}}$ ?

'Which one, mine or yours?'

(37) a. A: Kupili smo nov stroj. 'We bought a new machine.'

B: *Katerega gen $_{\text {Kateri }}$ Kacc $^{*}$ pralnega $_{\text {gen }} /$ pralni $_{\text {acc }}$ ali *pomivalnega gen $/$ pomivalni ${ }_{\text {acc }}$ ?

'*Which, the clothes-washing one or the dish-washing one?'

b. A: Naredila je poskus. 'She conducted an experiment.'

B: *Katerega gen $_{\text {Kaǩen }} /$ Kacc $_{\text {? }}$ *Kemičnega $a_{\text {gen }} /$ Kemičen $_{\text {acc }}$ ali *biološkega $a_{\text {gen }} /$ biološki ${ }_{\text {acc? }}$ ?

'Which?/What kind? Chemical or biological?'

c. A: Prinesla je stol. 'She brought a chair.'

B: *Katerega $a_{\text {gen }} /$ Kateri $_{\text {acc }}$ ? "Lesenega $a_{\text {gen }} /$ Leseni $_{\text {acc }}$ ali*plastičnega $_{\text {gen }} /$ plastični $_{\text {acc }}$ ? 'Which one? The wooden one or a plastic one?'

The examples in (35) and (36) are fairly standard illustrations of the OA and require no comment. Although the effect in (37) is real, speakers I have consulted differ over the judgments reported. All state that (37a) is awful with the genitive (as is one in its English translation), but that in (37b) the genitive is perfectly normal and that in (37c) the accusative seems dubious. Be that as it may, these judgments about the felicity of the OA in (37) depend not on the traditional adjectival classification, but rather derive from a completely different property of certain adjective-noun collocations: to the extent that the interpretation of the modifier is understood as idiosyncratically depending on the missing noun, a pro $_{\mathrm{N}}$ analysis of the gap is unavailable. And since the OA arises as a consequence of the adjective undergoing concord with a silent pronoun, if the adjective cannot be properly interpreted when merged with a pro $_{\mathrm{N}}$, then the genitive has no source and the OA fails. It thus comes as no surprise that the accusative rather than the genitive is used in (37a), where pralni and pomivalni go part and parcel with stroj. In sum, the restrictions on the viability of the OA are indeed semantic, as Peti-Stantic claims, but along very different lines.

\subsubsection{The Ellipsis Option}

The second confound relates to the provenance of the accusative when the OA is impossible. Accusative is of course the expected form, reflecting agreement with the missing noun, and as such it has a straightforward account: ellipsis. Ellipsis is indeed the only alternative in other Slavic languages with bare adjectives, since they lack pro $_{\mathrm{N}}$. I take simple nominal ellipsis to be deletion (non-pronunciation) of syntactically present material in the course of so-called Spell-Out, that is, the mapping to Phonetic Form (PF). Instead of pro $_{\mathrm{N}}$, it is possible to have an NP which has been elided, hence does not culminate in acoustic instantiation. Adjectives will necessarily 
agree with the elided NP, giving rise to the "nominative" accusative instead of the OA. Representing ellipsis as strike-through, we can thus treat (37aB) as follows:

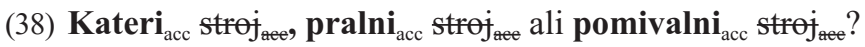

Variation in judgments is also expected since there is a competition between a pro $_{\mathrm{N}}$ analysis and an ellipsis analysis in the speaker's mind. ${ }^{19}$ Although pro $_{\mathrm{N}}$ is in general greatly preferred, when it is not viable because the adjective can only be interpreted by virtue of the missing noun, then ellipsis is the only alternative. However, as discussed in Franks (in press), the fact that there are two distinct ways to obtain nominal gaps in Slovenian ( rro $_{\mathrm{N}}$ and nominal ellipsis) makes it is also probable that different speakers employ these in different ways.

R. Žaucer (p. c.) provides a discourse analysis argument in support of my claim that the accusative implicates ellipsis. He reports the dialog in (39a) from a television program, but notes that the exchange in (39b) would also have been possible. In (39a) the silent noun is pro $_{\mathrm{N}}$, whereas in (39b) it is pir 'beer': ${ }^{20}$

(39) a. Waiter: Kaj boš? Kaj prnesem? 'What will you have? What shall I bring?' Customer: En pir. 'A beer.'

Waiter: Kašnga $a_{\text {gen }}$ pa? 'Which one?/What kind?'

Customer: Ta velzga $a_{\text {gen }} /$ / Ta velk $_{\text {acc }}$ 'A large one./A pint.'

b. Waiter: Kaj boš? Kaj prnesem? 'What will you have? What shall I bring?'

Customer: En pir. 'A beer.'

Waiter: Kašn ${ }_{\text {acc }}$ ? 'Which?/What kind?'

Customer: Ta velk acc. $/ *$ Ta velzga gen 'Large./A pint.'

Žaucer points out that since pir in (39) occurs immediately before the question word, both alternatives are viable. However, when pir does not occur immediately before the question word, only the long form is acceptable. That is, in (40), if a customer simply asks for a large beer without the antecedent pir, then ellipsis is impossible, and only pro $_{\mathrm{N}}$ can be used; hence, the OA is the only possibility:

(40) Živjo, dej mi enga $a_{\text {gen }} / * \mathbf{e n}_{\text {acc }}$ ta velzga $a_{\text {gen }} / *$ ta velk acc .

'Hi, give me a large one [=a pint].'

${ }^{19}$ Indeed, R. Žaucer (p. c.) comments about Peti-Stantić's (37b, c) that these "feel a bit . . . elliptical, i.e., like there's an unpronounced eksperiment [or stol] there".

${ }^{20}$ This colloquial particle-like definite marker $t a$ is described by Marušič and Žaucer (in press) as marking what they call "type definiteness." They argue that $t a$ can change a qualitative adjective into a classifying (i.e., relational) adjective. While for speakers I have consulted there is no interaction between $t a$ and the OA, Peti-Stantić (2009) reports judgments in which $t a$ is incompatible with the OA. This variation could be an interesting fact. It is possible that speakers fall into two groups, consistently using either the accusative or the genitive both with classifying adjectives as in (37) and with adjectives preceded by $t a$. 
Žaucer adds that for him the contrast between (39) and (40) is "crystal clear." The discourse context in which (40) is uttered can only mean the customer is requesting a pint of beer. This shows quite clearly that the OA involves deep, not surface anaphora: since it does not need a linguistic antecedent, the structure must involve pro $_{\mathrm{N}}$ rather than ellipsis. Hence only the genitive is acceptable in (40).

Similarly, Slovenian has certain "lexicalized" $t a+$ adjective collocations with nominal meanings, which I would analyze as appearing inside an NP headed by pro $_{\mathrm{N}}$. Examples provided by Žaucer include: ta kratek'a shot', ta beu 'quisling/WWII Home Guard', ta rdec 'commie', ta mau 'little one'. Interestingly, the OA is obligatory with these:

(41) Živjo, dej mi enga gen $/$ en $_{\text {acc }}$ ta kratkega $_{\text {gen }} / *$ ta $_{\text { }}$ ratek $_{\text {acc. }}$ 'Hi, give me a short one [=a shot $].$

The accusative form reflecting ellipsis is inapplicable because there is never a noun in the first place that could be elided. Instead, the only analysis available to the speaker is the pro $_{\mathrm{N}}$ one. Finally, the fact that such lexicalized adjectival expressions require the OA suggests that nominal use of adjectives in Slovenian in general may involve an adjective modifying syntactic pro $_{\mathrm{N}}$ rather than actual nominalization of the adjective.

\subsection{Slovenian Noun Phrase Structure in its South Slavic Context}

This section takes the analysis of the OA as a point of departure for examination of the extended nominal projection in Slovenian and related languages. In this context, recall P\&O's question (6.7): Why Slovenian-what is particular to Slovenian in the OA phenomenon, and what is more general?

\subsubsection{A Brief Recap and a Digression}

As pointed out by Rappaport (2009), P\&O's claim that what renders Slovenian special is that pronouns are animate cannot be correct, ${ }^{21}$ since this is hardly unique to Slovenian. Given that animacy of pronouns per se can hardly be the key factor giving rise to the OA, Rappaport proposes instead that the special property of Slovenian pronouns is their capacity to display I/S. This is, I will argue, an important but not the crucial part of the story. Under my account, the crucial element is the existence of pro $_{\mathrm{N}}$. The silent pronoun, together with the facts that pronouns are [+animate] and that the APR thus makes pro $_{\mathrm{N}}$ genitive when masculine singular, is what gives rise to the OA. It is this combination of factors that makes Slovenian special.

The idea that the OA depends on the possibility of I/S is very appealing, but the two phenomena are not completely coextensive. For one thing, other Slavic languages

21 "Under the correct analysis the only thing that is particular to Slovenian is the marking [+animate] on pronouns" (p. 457). 
exhibit something like the Slovenian OA. In Polish, when certain masculine singular inanimate nouns are orphaned, speakers allow genitive adjectives in accusative contexts:

(42) a. A. Jan kupił nowy ${ }_{\text {acc }}$ samochód $_{\text {acc }}$. B. A ja chcę kupić starego ${ }_{\text {gen }}$.

b. A, Ja widzę duży $\mathrm{acc}_{\text {samochód }}$ acc.

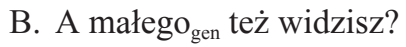

'Jan bought a new car.'

'And I want to buy an old (one).'

'I see a big car.'

'And do you also see a small (one).'

Like Slovenian, Polish only does this with masculine singular nouns, which presumably relates to the fact that, in Polish as in Slovenian, the masculine singular clitic pronoun go is the only one that is neutral between genitive and accusative (i.e., there is no distinct accusative form so the genitive substitutes, regardless of animacy). Feminine $j a$, neuter $j e$, and non-virile plural je are unambiguously accusative, the genitive forms being jej, go, and ich, respectively (virile ich is irrelevant since it invokes the APR regardless). ${ }^{22}$

Much closer to Slovenian is Bosnian/Croatian/Serbian. And indeed, although it lacks the OA construction per se, BCS does show some behaviors which tantalizingly resemble the OA. To see this, recall first P\&O's insight that the Slovenian OA involves some kind of agreement with a pronoun, an idea which my account directly adopts in the guise of pro $_{\mathrm{N}}$. They supported this by noting that similar agreement occurs when the pronoun is overt, as in (43), where the pronominal clitic and a quantifier agree:

(43) a. Želel sem jo pojesti $v \boldsymbol{s o}_{\text {acc }}$.

b. Želel sem ga pojesti $v s e g a_{\text {gen }} / * v e s_{\text {acc }}$.
'I wanted to eat it (feminine) all up.'

'I wanted to eat it (masculine) all up.'

Crucially, the floated quantifier $v s$ - 'all' in (43b) appears in the genitive rather than the accusative, despite the fact that the clitic ga refers to something inanimate. Similarly, compare (44a) and (44b):

(44) a. Včeraj smo našli stol acc $_{\text {pomazan }}$ acc $\mathrm{s}$ krvjo. 'Yesterday we found the chair stained with blood.'

b. Včeraj smo ga našli pomazanega $a_{\text {gen }} / *$ pomazan $_{\text {acc }}$ s krvjo. 'Yesterday we found it [=chair] stained with blood.'

${ }^{22}$ However, like English one and unlike the Slovenian OA, this Polish genitive can only apply when the missing nominal is non-specific; otherwise the accusative must be used. I have no idea however why speakers accept it with some nouns and not others; clearly this is a problem worthy of further study. I thank I. Dębowska-Wosik (p. c.) for help with the data. 
Even though $g a$ in (44b) is identical in reference to stol 'chair' in (44a), and as an adjective pomazan- 'stained' should have a choice of forms, it opts for the animate possibility, in agreement with ga. Presumably, the only difference between these (b) examples and the OA is that the latter implicates a null pro $_{\mathrm{N}}$, something peculiar to Slovenian.

If so, we might expect to find agreement with overt pronouns even in languages that lack $\operatorname{pro}_{\mathrm{N}}$. Strikingly, BCS displays a similar agreement pattern here as Slovenian. Consider the following BCS paradigm: ${ }^{23}$

(45) a. Ostavio sam stol prevrnutan acc $_{\text {. }}$

b. Ostavio sam ga prevrnutog ${ }_{\text {gen }} /$ prevrnutan $_{\text {acc }}$.
'I left the table overturned.'

'I left it [=table] overturned.'

BCS thus behaves exactly like Slovenian (44), in that the genitive case of the adjective in (45b) reflects obligatory formal matching with $g a$.

Another BCS phenomenon which suggests an affinity to the OA can be found in relative clauses. In BCS (46a), the relative pronoun exhibits two acceptable agreement possibilities: the genitive, matching pronominal morphological animacy, or the (nominative-like) accusative, matching nominal inanimacy. ${ }^{24}$ In addition, an anonymous Slovenski jezik reviewer observes that colloquially the genitive form čega also arises (instead of expected $\check{s} t a / s ̌ t o$ ) on inanimate pronouns after prepositions which govern accusative, as in (46b), showing that the "orphan" phenomenon is not restricted to relative clauses, but rather hinges in some way on pronominalization: ${ }^{25}$

(46) a. stol kojega $\mathbf{g e n}_{\text {gen }} / \mathbf{k o j i}_{\text {acc }}$ sam prevrnuo ...

'the table which I overturned ...'

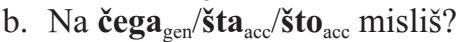

'What are you thinking about?'

Why should this be, especially when the secondary predicate in (45) must agree with $g a$ when it is present? To answer this question, consider the other relativization strategy available in BCS (and in Slovenian and many other languages). One can also employ the invariant complementizer što. When one does, an object clitic typically cooccurs. Under certain conditions, however, the resumptive clitic is often optional: ${ }^{26}$

${ }^{23}$ Thanks are due to W. Browne (p. c.) for pointing this out to me.

${ }^{24}$ Not surprisingly, since $g a$ is also neuter, neuter relative clauses exhibit the same behavior. A reviewer cites the following: (i) "Javno pismo" kojeg $_{\text {gen }}$ je napisao djelatnik ... 'A "public letter" which the employee wrote ...'

${ }^{25}$ A quick search admittedly returns only thousands of examples with čega, as opposed to millions with the accusative-nominative. This alternation is nonetheless worthy of more careful investigation.

${ }^{26}$ For discussion of the conditions, which seem to have to do with morphological syncretism, see Gračanin-Yüksek (2009), as well as Franks (in press). Note also that speaker judgments vary about whether the clitic can be left out. For a comprehensive treatment of resumptives in Slovenian (and other) relative clauses, see Chidambaram (2013). 
(47) stol što sam (ga) prevrnuo ...

'the table that I overturned (it) ...'

In Franks (in press), I argue for movement of a null operator $\varnothing$ to the SpecCP of the relative clause. ${ }^{27}$ Regardless of how this relativization strategy is formalized, there seems to be a parallelism between (46) and (47). In this context, note that Slovenian admits no optionality here, in either situation: ${ }^{28}$

(48) a. stol, katerega $a_{\mathrm{gen}} /{ }^{*} \mathbf{k a t e r i}_{\mathrm{acc}}$ sem prevrnil ... 'the chair which I overturned ...'

b. stol, ki sem * (ga) prevrnil ... 'the chair that I overturned it ...'

In sum, BCS exhibits some OA-like effects; agreement with a pronoun seems to reflect the formal animacy of that pronoun, but it lacks the ${ } r o_{\mathrm{N}}$ which gives rise to the Slovenian OA.

On the flip side, the possibility of $\mathrm{I} / \mathrm{S}$ is not completely unknown in BCS. According to speakers consulted, in the BCS counterparts to the examples in Slovenian (15), I/S is possible when I/R is pragmatically bizarre or ruled out. ${ }^{29}$ Hence, in contrast to Slovenian, (49a) must have I/R, but I/S emerges in (49b, c):

(49) a. Goran je vidio plava kola i Zoran ih je također vidio.

'Goran saw a blue car and Zoran also saw it/*one.'

b. Goran ima smeđi kaput i Zoran ga također ima.

'Goran has a brown car and Zoran also has *it/one.'

c. Goran ima pametnu ženu i Zoran je također ima.

'Goran has a smart wife and Zoran also has *it/one.'

An anonymous reviewer for Slovenski jezik remarks that such examples are "easy to find," offering the BCS exchange in (50) with I/S ga:

(50) a. Madrac je ko novi.

'The mattress is like new.'

b. Ja ga također imam, i dobro spavam isključivo na njemu.

'I have *it/one too, and slept well only on it.'

${ }^{27}$ Alternatively, à la Kayne, što-relativization could involve movement of the actual NP stol from object position.

${ }^{28}$ Thanks to R. Žaucer for confirming these examples.

${ }^{29}$ Thanks to A. Peti-Stantić (p. c.) and N. Todorović (p. c.), inter alia, for providing Croatian and Serbian judgments, respectively. Informal surveying suggests variation in the felicity of coercion of the I/S reading, possibly along regional lines. Runić (2013b) however reports that $\mathrm{I} / \mathrm{S}$ is regularly available in $\mathrm{BCS}$, with no restrictions beyond pragmatic ones. 
The fact that I/S can be coerced in BCS (and may even be widespread; cf. fn. 29) thus indicates that the possibility of $\mathrm{I} / \mathrm{S}$ is not enough to give rise to the OA. Instead, what happens in Slovenian is a complex conspiracy of $\mathrm{I} / \mathrm{S}$, the APR, and the availability of pro $_{\mathrm{N}}$.

\subsubsection{Nominal Projections: The Place of Clitics and pro $_{\mathrm{N}}$}

Adopting a finer nominal structure than just NP allows for variation in the locus of pronouns. In this vein, Rappaport (2009) proposes that Slovenian pronouns can be either "NP level" (the I/S possibility) or "DP level" (the standard I/R possibility), where DP serves to house referential features, and NP serves to house lexical information. Although I take this idea to be essentially correct, this association between features and projections cannot be absolute, since even in languages that lack articles (implying that definiteness does not project its own DP), NPs have referential value. A similar point can be made about case, which can either project its own KP (kase phrase) or not. In this section, we therefore consider how the Slovenian nominal domain might fit into more general patterns of nominal structure.

Nominals have features for case and specificity, inter alia, but how these features are expressed differs. The variation is a matter of whether features are borne by a separate functional head or not. There are thus canonical "DP languages" such as French or English and canonical "NP languages" such as Latin or Russian. Bošković $(2005,2008,2009)$ explores this traditional theme and elaborates on it, taking it in a host of novel directions. Details aside, one could posit rough structures for representative languages as follows:
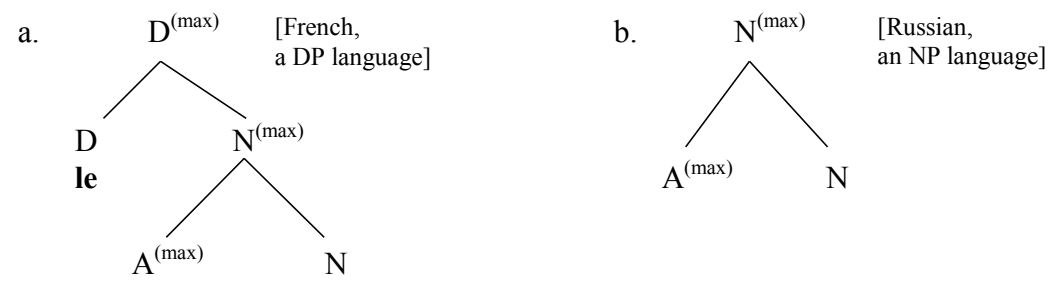

Russian has neither articles nor pronominal clitics. As a DP language, French has articles, but (unlike English), it also uses them as pronominal clitics: in keeping with BPS, when DP does not branch, le functions both as $\mathrm{D}^{0}$ and $\mathrm{D}^{\max }$ (i.e., it is a head that is exhaustively phrasal), and hence can serve as a direct object clitic. In the Slavic languages, on the other hand, pronominal clitics resemble the case morphemes of these languages. These are consequently $\mathrm{K}^{0}$ rather than $\mathrm{D}^{0}$ heads, as in the $\mathrm{BCS}$ structure in (51a). While definiteness is ordinarily not independently realized, it can be, as in the Bulgarian “KP-over-DP” structure in (51b). ${ }^{30}$

${ }^{30}$ See Franks and Rudin (2005) or Franks (2009) for justification of the DP-over-KP structure for Bulgarian, which supersedes the KP-less analysis in Franks (2001). In Macedonian, as 
$(51)$

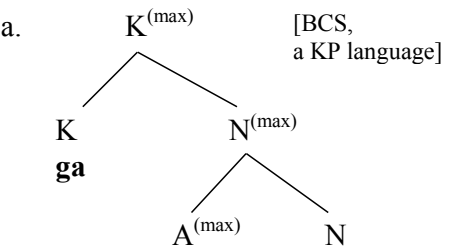

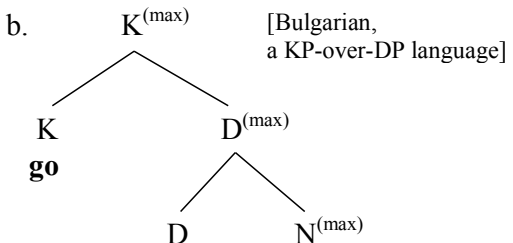

There are many associated properties that distinguish BCS from Bulgarian. The most obvious one, of course, is the fact that only in Bulgarian is definiteness morphologically marked (as inflection):

(52) a. grad-ât 'the city'; gradove-te 'the cities'

b. [golemi-jat] grad 'the big book'; [golemi-te] gradove 'the big cities'

c. [dosta [golemi-te]] gradove 'the quite big cities'; [najxubavi-te] golemi gradove 'the nicest big cities'

The most salient DP language syntactic property is the possibility of left-branch extraction in BCS, as in (53a), versus its absence in attempted Bulgarian (53b):

(53) a. Kakva si kupio [e kola]?

b. *Kakva prodade Petko [e kola]?
'What kind of car did you buy?'

'What kind of car did Peter sell?'

As discussed at length by Bošković (2005), the extra layer of structure in DP languages inhibits extraction because it creates an additional "phase" projection above NP.

Slovenian seems to be developing from an NP language, with a general structure as in BCS (51a), into some kind of DP language. ${ }^{31}$ As noted in Franks (2007), Slovenian generally eschews left-branch extraction, patterning like DP languages: Slovenian (54b) thus behaves like Bulgarian (54c) and not like BCS (54a):

(54) a. Vukina odlazi ćerka.

b. *Milojkina odhaja hči. [cf. $\sqrt{ }$ Milojkina hci odhaja.]

c. *Novata prodade kola. [cf. $\checkmark$ Prodade novata kola.]
'Vuk's daughter is leaving.'

'Milojka's daughter is leaving.'

'S/he sold the new car.'

shown in Franks (2009), the pronominal clitic is evolving into an agreement marker; rather than moving from a non-branching KP to above VP, it is generated outside of VP in the first place.

${ }^{31}$ Bošković (2009a: fn. 20) similarly concludes his paper on Slovenian NPs with a lengthy footnote on the relevance of (the absence of) left-branch extraction in Slovenian, stating that he "wouldn't rule out the possibility that we are starting to witness a change here, i.e., the beginning of the emergence of a DP system, with the change starting with indefinite articles." 
However, as Despić (2013) shows, the impossibility of left-branch extraction does not depend on DP per se, but rather on any higher functional structure, since that would constitute a phase above NP. Given that clitics are syntactically (although not prosodically) the same in Slovenian as in BCS, I continue to assume that nominal projections culminate in KP. Slovenian may thus be evolving along Bulgarian lines, with a generic KP-over-FP structure:

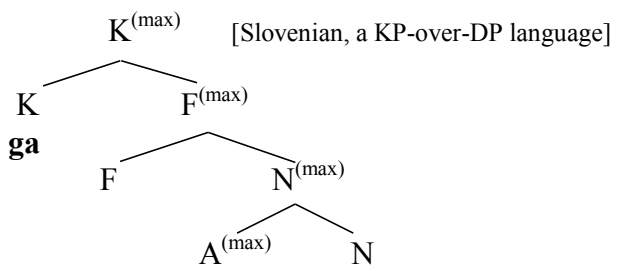

While the Slovenian nominal domain has additional functional structure, the language does not have obligatory determiners and cannot yet be equated with the DP of Bošković's typology. It does have some DP-like elements. For one thing, as mentioned above, colloquial Slovenian has a special definite marker $t a .^{32}$ Another striking fact is that Slovenian regularly employs en 'a' as an indefinite article. Perhaps, then, the "FP" in (55) should more perspicuously be labeled "DefP", since at least one likely occupant of $\mathrm{F}$ is the article en, as in the OA examples in (25). This likely constitutes an early stage in the development of a fully-fledged DP. Let us therefore make the descriptive move in (56). Additionally, Def provides a ready solution to the source of the I/S reading: the clitic has the option of merging in $\mathrm{K}$ or Def, the latter giving rise to I/S. Finally, pro $_{\mathrm{N}}$ must merge as $\mathrm{N}$ since it can further combine with adjectives.

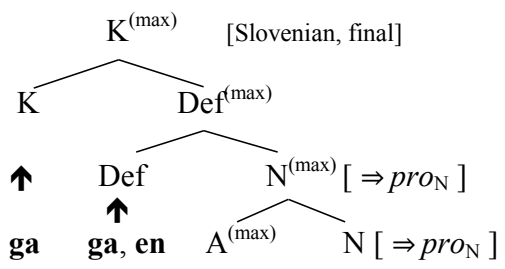

Also, since the KP level is only needed when a $\mathrm{K}$ (i.e., an $\mathrm{I} / \mathrm{R}$ clitic) is present, a nominal is often maximally DefP.

${ }^{32}$ See Marušič and Žaucer (in press) for discussion of $t a$. Interestingly, they place $t a$ APs under FP, above NP, and above APs that cannot take $t a$, in a way that is reminiscent of the FP structure for Slovenian in (55). 


\section{Clitic Doubling}

Another property of DP languages, added by Bošković (2008), is that only these admit clitic doubling. This generalization follows from the account in Franks and Rudin (2005) and is developed in Franks (2009). Essentially, doubling is only available when the extended nominal projection provides two sites for referential features, so that the nominal can be doubly instantiated. Hence in Bulgarian (57) the DP extracts out of KP, leaving the clitic behind. This can subsequently move to $\mathrm{V}$ as a nonbranching maximal projection: ${ }^{33}$

(57) a. Tjah nikoj ne gi pazi.

'Nobody is guarding them.'

b. Ivan go târsjat.

'They are looking for Ivan.'

It is therefore of particular interest that dialects of Slovenian, as discussed by Marušič and Žaucer (2009), also exhibit clitic doubling. Finally, consider also their (58), from Gorica Slovenian:

(58) a. Ma to $\mathbf{m e}_{\text {gen }}$ mene $_{\text {gen }}$ ne briga.

'But I don't care about this.'

b. Bi $\mathbf{m u}_{\mathrm{dat}} \operatorname{mogu} n j e m u_{\text {dat }}$ pustit.

'I should have left that for him.'

c. Jaz se $\mathbf{g a}_{\mathrm{gen}} n j e g a_{\text {gen }}$ spomnim še iz srednje šole.

'I remember him already from high school.'

d. Lahko jih acc/gen pa $n j i h_{\text {acc/gen }}$ vpraša.

'He can ask them.'

Marušič and Žaucer (2009) note that this doubling phenomenon is restricted to pronominal associates (although possibly not in all dialects that have it). As in Bulgarian - where doubling correlates historically with the rise of DP - the development of doubling in Slovenian suggests a more finely articulated extended nominal projection for Slovenian as well, in order to allow for both the clitic and its associate. In addition, the issue of why doubling is limited to occurring with pronominal associates may provide some further hints as to the details.

Given that (56) makes available two positions for clitics, we could imagine that clitic doubling in this dialect arises by taking advantage of both positions. Suppose

${ }^{33}$ Spanish, which doubles the D element, implying a "DP-over-KP" structure, instantiates the flip side of Bulgarian. (In standard Spanish KP splits into P+DP in the morphology, so that the preposition $a$ appears; cf. Franks 2009, in press.) 
that the $n j(e)$ - element that initiates all third person full forms is in fact $\mathrm{N}^{0}{ }^{34}$ Then, to form a tonic pronominal in Slavic NP languages (in which there is no doubling), as well as for the Slovenian non-doubling norm, it incorporates into (undergoes merger with) the clitic in $\mathrm{K}^{0.35}$

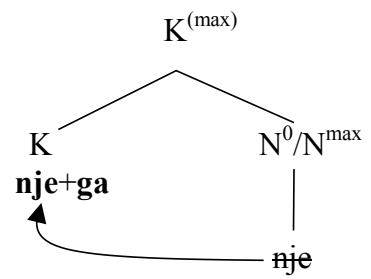

But the clitic can also be merged as Def ${ }^{0}$. Clitic doubling in Gorica Slovenian (59) can then be analyzed as having a structure in which the clitic merges at both points:

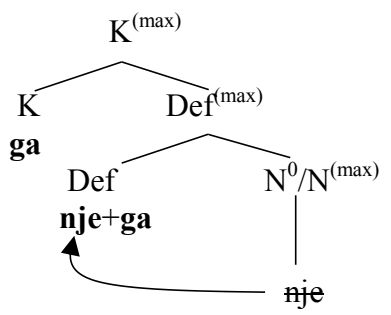

There are various technical ways of fleshing out the details, but under all of them the result is that the associate must be a full pronoun. Structure (60) has nj(e)- moving to the lower $g a$, with the upper one simply merged independently; Franks (in press) instead proposes excorporation of $g a$ from Def to K, and subsequent morphological restructuring of $[n j e+g a]$ in Def. ${ }^{36}$ Another approach might be for $n j(e)$ - to move as a phrase (alternatively, as "long head movement") over $g a$ in Def, directly to $g a$ in

\footnotetext{
${ }^{34}$ More precisely, a non-branching NP/N in the BPS system, which merges as a phrase but moves as a head.

${ }^{35}$ This $n j(e)$ - is arguably the same morpheme as the $-n j$ which appears after certain prepositions in many of the Slavic languages. This sort of N-to-P movement (or morphological "merger"), as in Polish nań 'on him/?her?', is largely archaic. Interestingly, this form is no longer gender bound; cf. Franks and King $(2000,152)$.

${ }^{36}$ These may be notational variants, especially if movement is analyzed as multidominance. The insight is that both occurrences of $g a$ instantiate the same element.
} 
$\mathrm{K}$. Under any of these scenarios, KP must be consistent in definiteness, thus njega can never be interpreted as indefinite- it is necessarily referential (and I/S is never available with tonic pronouns). That is, conflicting feature values for definiteness within the extended nominal projection lead to ill-formed semantics. KPs are always [+definite]; hence, no matter how clitic doubling is analyzed, one instance of the clitic must be a definite $\mathrm{K}^{0}$. Similarly, it makes sense to assume that the nomimal $n j(e)$ - is also [+definite], both historically and in light of fn. 35 .

\section{Excursus on Coordination}

A great deal of research has been conducted across diverse languages on the general problem of agreement with coordinated subject NPs; for Slovenian I rely on Marušič et al (in press). ${ }^{37}$ As in other languages, when faced with a coordination structure, Slovenian has at its disposal a variety of agreement strategies. Let us represent coordination as follows, that is, as a phrase headed by "\&," in keeping with the tenets of X'-syntax:

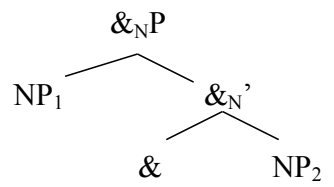

Note that the subscripted $N$ is intended to show that the categorical features of the projection of $\&$ derive (presumably through unification) with those of its complement (here, NP).

Given (61), how does agreement proceed? One possibility, which does not concern us here, is agreeing with the $\& \mathrm{P}$ dominating the coordinate structure. ${ }^{38}$ Another strategy is for the verb to target either $\mathrm{NP}_{1}$ or $\mathrm{NP}_{2}$ as its controller. In many languages, VS order facilitates agreement with $\mathrm{NP}_{1}$. This "first" conjunct agreement can be seen in BCS (62a), from Bošković (2009: 456), or English (62b): ${ }^{39}$

${ }^{37}$ For an overview of strategies and data, see Corbett (2006). Some recent studies include Benmamoun, Bhatia, and Polinsky 2009, Bošković 2009b, and É. Kiss 2012.

${ }^{38}$ The \&P can have its feature values determined by some sort of "resolution" rule (which mediates the features of the conjuncts) or by default; see Corbett 2006 for details.

${ }^{39}$ Note that agreement in (62) with the distant conjunct (i.e., $\mathrm{NP}_{2}$ ) is unacceptable; employing instead *uništene 'destroyed $\mathrm{d}_{\text {fem.pl }}$ ' would render BCS (62a) ungrammatical. English There were [a dog and three cats] scratching at the door is highly prescriptive and in any event does not reflect distant conjunct agreement but rather plural agreement with $\&_{\mathrm{N}} \mathrm{P}$, since for me it has the same status as There were [a dog and a cat] scratching at the door. 
(62) a. Juče su uništena ${ }_{\text {neut.pl }}\left[\right.$ sva sela $_{\text {neut.pl }}$ i sve varošice fem.pl $\left._{\text {. }}\right]$. 'Yesterday were destroyed all villages and all towns.'

b. There was [a dog and three cats] scratching at the door.

In Chomsky's minimalist Probe-Goal system, the verb can probe down the tree looking for an NP to agree with, hence there was a dog at the door versus there were three cats at the door, but with a coordinated structure, the closest goal can be the highest (or leftmost) target, namely $\mathrm{NP}_{1}$, assuming the $\left[\& \mathrm{P} \mathrm{NP}_{1}\left[\& \mathrm{NP}_{2}\right]\right.$ ] structure in (61). This is the strategy of concern in the present section. Yet another possibility is facilitated by SV order, where the verb agrees just with $\mathrm{NP}_{2}$; this kind of "last" conjunct agreement is possible in BCS (63a), but not English (63b):

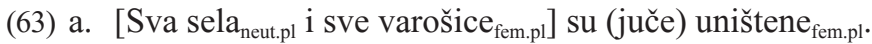
'All villages and all towns were destroyed yesterday.'

b. *[Three cats and a dog] was scratching at the door.

These are sometimes unified under the rubric of the "closest" conjunct determining agreement, ${ }^{40}$ but it seems to me that - whatever is going on in the SV examples - (62) calls for a Probe-Goal hierarchical solution.

In this context, Slovenian presents a typologically rare alternative, "distant" first conjunct agreement (FCA):

(64) $\left[\right.$ Radirke $_{\text {fem.pl }}$ in peresa $\left.a_{\text {neut.pl }}\right]$ so se prodajale fem.pl $_{\text {najbolje. }}$

'Erasers and pens sold the best.'

The default masculine plural is always possible and hence, as a reviewer reminds me, serves as the literary standard. Nonetheless, as discussed by Marušič et al (in press), the pattern in (64) is a very real one: their experiments show that apparent FCA with $\mathrm{SV}$ order is generally available in Slovenian, although this option is typically dwarfed by the masculine default and closest conjunct options. Overall they report that "nonmasculine first conjuncts triggered preverbal FCA in 14\% of cases." It is most robust (and most clear) in examples where neither conjunct is masculine, since the masculine is also the default. For example, when $\mathrm{NP}_{1}$ is feminine plural and $\mathrm{NP}_{2}$ is neuter plural, as in (64), they report $22 \%$ distant $\mathrm{FCA}$, and $26 \%$ when $\mathrm{NP}_{1}$ is neuter plural and $\mathrm{NP}_{2}$ is feminine plural. In BCS, on the other hand, distant FCA is excluded; (65) is thus not a possible alternative to (63a):

(65) *[Sva sela neut.pl $_{1}$ s sve varošice fem.pl $\left._{\text {f }}\right]$ su (juče) uništena $a_{\text {neut.pl }}$.

40 "Closest" reflects a standard view, as expressed by Marušič et al (in press) and Benmamoun, Bhatia, and Polinsky (2009), who treat the phenomenon in OV languages. Bošković (2009b), however, puts forward a structural rather than linear account. 
Bošković (2009b) takes the fact that hypothetical BCS (65) is simply underivable in his system as an advantage, and is otherwise dubious that distant FCA exists at all. ${ }^{41}$

However, if this is a true difference between Slovenian and BCS, it is possible that it is the availability of DefP that gives rise to the distant FCA option in Slovenian. The relevant structure is given in (66):

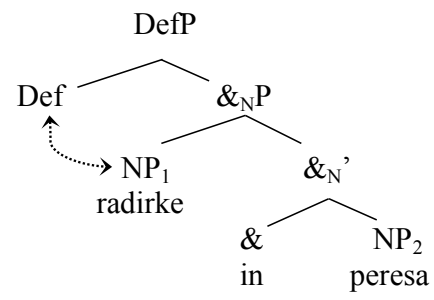

The idea is that FCA can be obtained by Def probing down the tree and getting its gender/number features valued by the closest goal, namely $\mathrm{NP}_{1}$, radirke. The participle then agrees with DefP, giving rise to apparent FCA even when the subject precedes the DefP. Of course, this account raises the obvious question of why, if a $\mathrm{D}$ element can mediate as in (66), distant FCA is so typologically rare. Notice that the same question arises about the OA, and my answer to both is that it must be a consequence of Slovenian being in a transitional, incipient DP stage. While the rarity of Slovenian-style distant FCA indicates that (66) cannot be available in true DP languages, ${ }^{42}$ it does seem that distant FCA might be emerging in south-eastern Serbian (Torlak) dialects, which are transitional between Serbian, Macedonian, and Bulgarian, and hence also display some DP properties. ${ }^{43}$ As noted, speakers of standard BCS eschew distant FCA. The question then arises of whether speakers of western Torlak varieties tolerate distant FCA (since these dialects retain gender distinctions in the plural). While I do not know the answer to this, Boban Arsenijević (p. c.) finds FCA only slightly degraded in his dialectal (67a): ${ }^{44}$

${ }^{41}$ In personal communication he writes that he is skeptical about the existence of distant FCA in Slovenian, and comments that extraneous factors such as processing, length, and discourse prominence might "affect agreement for irrelevant reasons."

${ }^{42}$ The need to limit (66) raises interesting questions. Possibly the correct analysis involves $\mathrm{NP}_{1}$ raising to SpecDefP (except that Slovenian does not tolerate left-branch extraction/coordinate structure constraint violations); possibly \&P must coordinate DPs.

${ }^{43}$ See Runić (2013a) for discussion of clitic doubling and other DP language diagnostics in "Prizren-Timok Serbian."

${ }^{44}$ Arsenijević is from Niš, unfortunately not exactly the right area; speakers from the Prizren area would need to be consulted. 
(67) a. ? Livade $_{\text {fem.pl }}$ i polja neut.pl $_{\text {sve izgorele }}$ fem.pl od sušu.

'The meadows and fields are all burnt from the drought.'

b. *Polja neut.pl $_{\text {i livade }}$ fem.pl $_{\text {sve izgorela }}$ neut.pl od sušu.

'The fields and meadows are all burnt from the drought.'

Some speakers of the "standard" (and replacing sve with standard putpuno, od sušu with standard od suše, and adding the auxiliary su) also report a diminished effect in (67a) vis-à-vis (67b), but most find both attempts at distant FCA in (67) equally impossible. ${ }^{45}$ There is thus clearly considerable room for further research here.

\section{Some Problems}

This section mentions two DP language diagnostics that Slovenian seems to fail. The first concerns the interpretation of en. Note that one is also used in NP languages, but only with a specific as opposed to true indefinite reading. Thus, Russian odnu in (68) can only mean the speaker has a specific American actress in mind. Its Slovenian counterpart in (69) is similar (unlike English with an, which also allows a generic or "indefinite" reading): ${ }^{46}$

(68) On dumaet, čto ja poxoža na odnu amerikanskuju aktrisu.

'He says that I look like a particular/*an American actress.'

(69) Meni, da sem podobna eni ameriški igralki.

It thus seems that en might imply specificity rather than true indefiniteness, and in this regard cannot be taken as a compelling argument for additional functional structure. On the other hand, in other contexts en has the expected effect. So, although one would normally respond to (69) with the question Kateri? 'Which one?', this response could then be countered by Ma, kar eni. 'Well, just some (actress).' The fact that focusing kar can bring out an indefinite reading is supported by examples of indefinite en supplied by L. Marušič, (70b) reflecting colloquial phonology:

(70) a. Rekel je, da sem kot ena filmska igralka.

'He said that I am like a (female) film star.'

b. Reku je, da sm ku en američan.

'He said that I am like a (male) American.'

${ }^{45}$ B. Arsenijević (p. c.) suggests that the problem with distant FCA in (67b) is the neuter, which "is not really a gender value" since "its case forms are also syncretic with masculine forms." As in Slovenian, masculine is irrelevant because it is the default.

${ }^{46}$ Thanks to R. Žaucer and L. Marušič for helpful discussion, and to Ala Simonchyk for corroborating the Russian. 
A further problem with positing additional structure is that, as argued persuasively by Despić (2013), any distinct functional projection above NP creates a phase. One phase effect is the obviation of disjoint reference in the English versions of the BCS sentences in (71), since the DP in English obviates c-command out of the subject:

(71) a. $*{ }_{\mathrm{NP}}$ Kusturicin [ ${ }_{\mathrm{NP}}$ najnoviji film] $]$ ga je zaista razočarao.

'[DP Kusturica's [NP latest film]] really disappointed him.'

b. *[NP Njegov [NP najnoviji film]] je zaista razočarao Kusturicu.

'[DP His [latest film]] really disappointed Kusturica.'

In BCS, on the other hand, the possessives Kusturicin and njegov are adjoined to NP, hence c-command $g a$ and Kusturicu, leading to a violation of Binding Principle B in (71a) and $\mathrm{C}$ in (71b). If Slovenian had an additional functional projection above NP, one might expect judgments to resemble English here. However, they seem to pattern like those given for BCS in being unacceptable with coreference. The following were provided by R. Žaucer (p. c.):

(72) a. *Naberšnikov najnovejši film ga je globoko razočaral.

b. ?Njegov najnovejši film je Naberšnika globoko razočaral.

Some Slovenian speakers, however, accept coreference in other, ostensibly comparable examples (but so do some speakers of BCS). Both of these problems thus also raise questions for further research.

Indeed, my analysis of the $\mathrm{OA}$ is independent of my arguments for possible functional structure above NP. It was argued that what makes Slovenian special for the OA is the availability of a pro $o_{\mathrm{N}}$ as a vocabulary item. But since this enters the structure as a noun, it in no way implicates an FP between KP and NP. That is, the Slovenian extended nominal projection could still be just like BCS (51a), at least so far as the analysis of the OA is concerned. In this context, note that Runic (2013a, $2013 \mathrm{~b}$ ) proposes that clitics in NP languages are simply nouns. If so, and given the problems just pointed out, one might reject the analysis developed in sections 2 and 3 above in favor of the simpler KP-over-NP structure. However, instead of being generated directly in $\mathrm{K}^{0}$, clitics would be treated as $\mathrm{N}$ heads that raise to $\mathrm{K}^{0}$. This would be true of both Slovenian and BCS standards. Doubling dialects would then be the result of directly merging the clitic in $\mathrm{K}^{0}$, and introducing the associate (which could and, in Nova Gorica Slovenian as described by Marušič and Žaucer 2009 must, be a tonic pronoun) under NP. This approach would however encounter a problem of its own: Why is doubling not more pervasive? Under my system, doubling is a consequence of having two nodes which can house referential/definite features, as in Bulgarian (51b), and it only arises in other South Slavic dialects to the extent that there is a second potentially referential FP, in addition to KP. 


\section{Final Reflections}

This paper has explored the Orphan Accusative construction from the perspective of Slovenian itself, variation in South Slavic nominal phrases, and principles of Universal Grammar. I have argued that the OA phenomenon derives from the Accusative Prediction Rule coupled with the existence, in Slovenian, of a nominal pro. For all intents and purposes, the Slovenian pro $_{\mathrm{N}}$ was shown to be a silent version of English one. In order to make the account work, however, it was essential that this pro $_{\mathrm{N}}$ be "rich" in the sense of bearing the morphological feature [+animate], so that it could interact appropriately with the APR in (10).

Consider now why there should be such a rule in the first place. The answer, I suggest, can be found in the exigencies of surface morphology; it is no accident that (10) only applies when there is no autonomous accusative form. Thus, this is a rule of PF implementation that instructs the morphology to look to a different cell in the paradigm if and only if, in seeking an accusative form, the rule encounters a gap. But this still does not explain why pronouns should fail to reflect natural animacy, opting to behave as if [+animate] instead. This mysterious fact is crucial not only to the Slovenian OA, but also to the workings of Slavic pronouns in general.

Here I propose that the reason is because when the referent of the pronoun is inanimate, (10b) actually fails to give any result at all. Slavic pronouns are essentially case morphemes. In the nominative, however, I contend that there are no case morphemes: the final vowel (or zero) on "nominative" nouns in fact marks gender and number, not case. ${ }^{47}$ This is why caseless verbal participles and predicate adjectives utilize them: these items agree only in gender/number. The APR has no difficulty here, however, because it is able to return a concrete form despite the lack of morphological case. With pronouns, however, there is a problem: since there is neither substantive stem nor functional material desinence, there can be no morphological exponent at all. All Slavic languages solve this problem with suppletion, co-opting a demonstrative stem for the third person nominative. ${ }^{48}$ This is typically neutral $n$ - or distal $t$ - (also proximal $v$-), for example, Slovenian on 'he' or Bulgarian toj 'he'. My claim, then, is that P\&O's (11) _ “Slovenian pronouns behave morphologically as if they were animate" - is the by-product of a morphologically impoverished paradigm; it is resorted to because there is no nominative in the paradigm at all. Instead of ineffability, the situation is rescued by a morphological rule that changes the feature value [-animate] to [+animate], allowing access to the masculine/neuter singular genitive form in the pronominal paradigm. Interestingly, if this scenario is on the right track, technically only those pronouns that lack a distinct accusative entry should be intrinsically [+animate]. Hence, whenever a pronoun

${ }^{47}$ Ž. Bošković (p. c.) speculates that my contention about nominative morphology in Slavic might follow from the absence of TP, a claim he has made for more general typological reasons.

${ }^{48}$ First and second person, already being naturally [+animate], pose no problem for (10), but still involve suppletion. 
does have a distinct accusative - as do many Slavic pronouns, depending on the language - the APR is not invoked and Spell-Out has no occasion to avail itself of the rule assigning [+animate]. ${ }^{49}$ I thus think of the APR in Distributed Morphology terms: the feature [-animate] is literally changed to [+animate], thereby enabling (10) to return an output form. ${ }^{50}$

Let us return, finally, to the outstanding problem posed by the Orphan Accusative: Why is that pro $_{\mathrm{N}}$ - which after all has no surface morphological form-also ends up as [+animate]? In the GB tradition it has long been established that empty categories have case and phi features. ${ }^{51}$ Whenever pro $_{\mathrm{N}}$ is [-animate] by virtue of the natural gender of its antecedent, the morphology ends up changing that feature value to [+animate]. In the system I have outlined, one might imagine a solution in which (10a) applies first, seeking a nominative form if [-animate]. Only if that fails does the morphological rule change the value to [+animate] in attempt to exploit (10b). With overt pronouns this strategy is successful, providing the genitive entry as its output. Spell-Out of pro $_{\mathrm{N}}$, of course, will find nothing morphological to match with, be it [-animate] or [+animate]. Perhaps, then, whenever pro $_{\mathrm{N}}$ is [-animate], since the first clause of the APR returns nothing, the morphological rule that changes the value to [+animate] is invoked. This is of course a vain attempt, since (10b) returns nothing as well. Pro $_{\mathrm{N}}$ nonetheless remains animate, as evidenced by the agreement of adjectives and is, in the end, exactly the Orphan Accusative effect grappled with in this paper. ${ }^{52}$

\section{References}

Aoun, Joseph, Elabbas Benmamoun, and Dominique Sportiche. 1994. Agreement and conjunction in some varieties of Arabic. Linguistic Inquiry 25: 195-220.

Benmamoun, Elabbas, Archna Bhatia, and Maria Polinsky. 2009. Closest conjunct agreement in head final languages. Linguistic Variation Yearbook 9: 67-88.

Bošković, Željko. 2005. On the locality of left branch extraction and the structure of NP. Studia Linguistica 59: 1-45.

Bošković, Željko. 2008. What will you have, DP or NP? In NELS 37: Proceedings of the 37th annual meeting of the North East Linguistic Society, vol. 1, ed. by Emily Elfner, and

\footnotetext{
${ }^{49}$ This means that, unlike $g a$, the Slovenian clitic pronoun jo 'her, it', for example, can be either [+animate] or [-animate]; unfortunately, since animacy plays no role in the grammar here that I can think of, there is no way to tell.

${ }^{50}$ This view can be contrasted with that of Rappaport (2009), who sees the APR as a "lexical redundancy rule" to guarantee that "[+pronoun $] \leftrightarrow[+$ animate $] . "$

${ }^{51}$ This can easily be demonstrated through predicate adjective agreement, e.g., PRO in Italian is masculine plural: Come smetter di [PRO essere nervosi $\boldsymbol{i}_{\mathrm{mpl}}$ ]? 'How to stop being nervous?'. Note also that in general $\mathrm{PRO}_{\text {arb }}$ is always animate (and human).

${ }^{52}$ Under this scenario, although I can think of no way to test it, every pro $_{\mathrm{N}}$ ends up [+animate], regardless of case or phi features.
} 
Martin Walkow, 101-114. Amherst: University of Massachusetts, Graduate Linguistic Student Association.

Bošković, Željko. 2009a. The NP/DP analysis and Slovenian. In Proceeding of the University of Novi Sad Workshop on Generative Syntax 1, 53-73. Novi Sad: University of Novi Sad.

Bošković, Željko. 2009b. Unifying first and last conjunct agreement. Natural Language and Linguistic Theory. 27(3): 455-96.

Chidambaram, Vrinda. 2013. On resumptive pronouns in Slavic. PhD diss., Princeton University.

Chomsky, Noam. 1995. Bare phrase structure. In Evolution and Revolution in Linguistic Theory, ed. by Héctor Campos, and Paula Marie Kempchinsky, 51-109. Georgetown University Press.

Corbett, Greville G. 2006. Agreement. Cambridge: Cambridge University Press.

Despić, Miloje. 2013. Binding and the structure of NP in Serbo-Croatian. Linguistic Inquiry 44(2): 239-270.

É. Kiss, Katalin. 2012. Patterns of agreement with coordinate noun phrases in Hungarian. Natural Language and Linguistic Theory 30: 1027-106.

Franks, Steven. 1999. X'-invisibility, derivational c-command and one-substitution. Linguistic Analysis 29: 1-8.

Franks, Steven. 2001. The internal structure of Slavic NPs, with special reference to Bulgarian. In Generative Linguistics in Poland: Syntax and Morphosyntax, ed. by Adam Przepiórkowski, and Piotr Bański, 5-69. Instytut podstaw informatyki PAN.

Franks, Steven. 2007. Deriving discontinuity. In Studies in Formal Slavic Linguistics, ed. by Franc Marušič, and Rok Žaucer, 103-20. Frankfurt: Peter Lang.

Franks, Steven. 2009. Macedonian pronominal clitics as object agreement markers. In A Linguist's Linguist: Studies in South Slavic Linguistics in Honor of E. Wayles Browne, ed. by Steven Franks, Vrinda Chidambaram and Brian Joseph, 189-221. Bloomington, IN: Slavica.

Franks, Steven. In press. The Slovenian orphan accusative and noun phrase structure. In The Nominal Constructions in Slavic and Beyond (Studies in Generative Grammar), ed. by Lilia Schürcks, Urtzi Etxeberria, and Anastasia Giannakidou. Berlin, New York: de Gruyter: Mouton.

Franks, Steven, and Tracy Holloway King. 2000. A Handbook of Slavic Clitics. Oxford University Press.

Franks, Steven, and Catherine Rudin. 2005. Bulgarian clitics as $\mathrm{K}^{\mathrm{o}}$ Heads. In Formal Approaches to Slavic Linguistics: The Columbia Meeting, ed. by Steven Franks, Frank Gladney, and Mila Tasseva-Kurktchieva, 104-16. Ann Arbor, MI: Michigan Slavic Publications.

Gračanin-Yüksek, Martina. 2009. On a matching effect in headed relative clauses. In Formal Approaches to Slavic Linguistics: The Cornell Meeting, ed. by Wayles Browne et al., 193-209. Ann Arbor, MI: Michigan Slavic Publications.

Herrity, Peter. 2000. Slovene: A Comprehensive Grammar. New York: Routledge.

Marušič, Franc, and Rok Žaucer. 2009. On clitic doubling in Gorica Slovenian. In A Linguist's Linguist: Studies in South Slavic Linguistics in Honor of E. Wayles Browne, ed. by Steven Franks, Vrinda Chidambaram, and Brian Joseph, 281-96. Bloomington, IN: Slavica.

Marušič, Franc, and Rok Žaucer. In press. A definite article in the AP-evidence from colloquial Slovenian. In The Nominal Constructions in Slavic and Beyond (Studies in Generative Grammar), ed. by Lilia Schürcks, Urtzi Etxeberria, and Anastasia Giannakidou. Berlin, New York: de Gruyter: Mouton.

Marušič, Franc, Andrew Nevins, and Bill Badecker. In press. The grammars of conjunction agreement in Slovenian. In Syntax.

Panagiotidis, Phoevos. 2003a. One, empty nouns, and $\Theta$-assignment. Linguistic Inquiry 34: 281-292. 
Panagiotidis, Phoevos. 2003b. Empty nouns. Natural Language and Linguistic Theory 12: $381-432$.

Perlmutter, David, and Janez Orešnik. 1973. Language-particular rules and explanation in syntax. In A Festschrift for Morris Halle, ed. by Stephen Anderson and Paul Kiparsky, 419-59. New York: Holt, Rinehart and Winston.

Peti-Stantić, Anita. 2009. Which case is the so-called "orphan accusative" in Slovene? Talk presented at American Association for the Advancement of Slavic Studies 41, Boston.

Rappaport, Gilbert. 2009. The "orphan accusative" in Slovene: Grammatical features lexicalized. Talk presented at Slavic Linguistics Society 4, Zadar.

Runić, Jelena. 2013a. Cliticization phenomena in languages 'on the border'. In University of Pennsylvania Working Papers in Linguistics: Proceedings of the 36th Annual Penn Linguistics Colloquium. Vol. 19: Iss. 1, Article 21, http://repository.upenn.edu/pwpl/vol19/iss1/21

Runić, Jelena. 2013b. A new look at clitics: Evidence from Slavic. In Formal Approaches to Slavic Linguistics: The Third Indiana Meeting, ed. by Steven Franks, Markus Dickinson, George Fowler, Melissa Witcombe, and Ksenia Zanon. Ann Arbor, MI: Michigan Slavic Publications: 275-288.

Toporišič, Jože. 2004. Slovenska slovnica. Založba Obzorja: Maribor.

Prispelo novembra 2012, sprejeto januarja 2013

Received November 2012, accepted January 2013

Navezovalni tožilnik, podvajanje, priredje, faze: o nominalni strukturi v slovenščini

Članek analizira navezovalni tožilnik v slovenščini z namenom, da bi razložil njegove posebnosti v podrobno razdelanem modelu strukture samostalniške zveze. Pri navezovalnem tožilniku se pridevnik, ki določa neživi samostalnik moškega spola $\mathrm{v}$ tožilniku, $\mathrm{v}$ primeru, ko je rabljen brez tega samostalnika, nepričakovano pojavi $\mathrm{v}$ rodilniško-tožilniški namesto $\mathrm{v}$ imenovalniško-tožilniški obliki. Izhodišče članka so ugotovitve Perlmutterja in Orešnika (1973), sledi pa utemeljevanje, da slovenščina pozna neizraženo zaimkovno prvino $\left(\right.$ pro $_{\mathrm{N}}$ ), ki se glede na njuno pravilo o obliki tožilnika obnaša kot neživo. Ko želimo odgovoriti na vprašanje, zakaj je navezovalni tožilnik posebnost slovenščine, skušamo utemeljiti, da njegovega izvora ne moremo pripisati posebnim semantičnim lastnostim rodilnika, širjenju oznake živosti na leksikalno raven ali (najbolj vabljivi) možnosti za razlago z identiteto pomena pri zaimkovnih naslonkah; za tovrstne razlage gl. npr. Peti-Stantić (2009) in Rappaport (2009). V nadaljevanju skušamo pojasniti obstoj slovenske zaimkovne prvine $\mathrm{pro}_{\mathrm{N}} \mathrm{V}$ kontekstu trenutnih modelov nominalne projekcije, ki razlikujejo med dvema tipoma sistemov: tipom s samostalniškimi zvezami in tipom z določilniškimi zvezami, pri 
čemer utemeljujemo, da se slovenščina razvija v drugi tip; gl. npr. Bošković (npr. 2005, 2008, 2009) ali Despić (2012).

Razdelek 1 je uvodni del. Razdelek 2, ki predstavlja glavnino članka, vsebuje pregled podatkov in alternativnih razlag, navaja argumente za pro $_{\mathrm{N}}$ ter prikazuje, kako je izkoriščeno pravilo o obliki tožilnika. Predstavljena je analogija med neizraženo slovensko zaimkovno prvino in angleškim zaimkom one. Razdelek se zaključi z umestitvijo slovenščine v širši kontekst (znotraj južnoslovanskih jezikov in splošneje) ter obravnavo podobnih pojavov v bosanskem/hrvaškem/srbskem jeziku, v katerih se zaimki, ki se nanašajo na neživo, včasih nepričakovano pojavijo v rodilniško-tožilniški obliki. Tu gre očitno za podobno širjenje pravila o obliki tožilnika kot pri slovenskem navezovalnem tožilniku. V preostalem delu članka namenjamo pozornost drugim možnim ustreznim diagnostičnim sredstvom, pri čemer skušamo dokazati, da v slovenščini nad samostalniško zvezo obstaja nekakšna določilniška funkcijska projekcija. Teoretično razpravljanje v razdelkih 3 in 4 nakazuje, da naslonsko podvajanje v narečjih (kot ga opisujeta Marušič in Žaucer 2009) zahteva nekakšno različico določilniške zveze, tako kot t. i. ujemanje z oddaljenim prvim sestavnikom. V razdelku 5 so navedeni nekateri možni problemi. Razdelek 6 prinaša zaključni razmislek o tem, kako bi lahko »preklop« med pravilom o obliki tožilnika in živostjo formalno umestili v okvir razpršene morfologije in zakaj ta proces zadeva predvsem zaimke.

\section{Orphans, Doubling, Coordination, Phases: On Nominal Structure in Slovenian}

This paper examines the Orphan Accusative (OA) construction found in Slovenian, with the aim of understanding its unique properties within an articulated model of noun phrase structure. In the OA, when an adjective modifying an inanimate masculine accusative noun appears without that noun, the adjective unexpectedly surfaces in the genitive -accusative rather than nominative-accusative form. Taking Perlmutter and Orešnik (1973) as a point of departure, I argue that Slovenian has a silent pronominal (a pro $_{\mathrm{N}}$ ) which, given their Accusative Prediction Rule (APR), behaves as if animate. Addressing the fundamental question of why the OA is unique to Slovenian, I argue that its provenance cannot be reduced to special semantics of the genitive, to lexical extensions of the animacy feature, or (most temptingly) to the availability of an "Identity of Sense" reading for pronominal clitics; see, for example, Peti-Stantić (2009) and Rappaport (2009) for discussion of these alternatives. I then attempt to understand the existence of Slovenian pro $_{\mathrm{N}}$ in the context of current models of nominal projection which contrast NP- and DP-type systems, arguing that Slovenian is developing into the latter; see, for example, Bošković (e.g., 2005, 2008, 2009) or Despić (2012). 
Section 1 is introductory. Section 2, which constitutes the bulk of the paper, reviews the data and alternatives, presents the pro $_{\mathrm{N}}$ account, and shows how it exploits the APR. An analogy is developed between the silent Slovenian pronominal and English one. The section culminates with a sketch of where Slovenian fits into the larger picture (in South Slavic and more generally), as well as a consideration of closely related phenomena in Bosnian/Croatian/Serbian in which pronominals with inanimate reference sometimes unexpectedly display genitive-accusative forms, apparently overextending the APR in similar fashion to the Slovenian OA. In the remainder of the paper, I turn to other potentially relevant diagnostics, attempting to push the idea that there is determiner-like functional material above NP in Slovenian. The speculative discussions in sections 3 and 4, respectively, suggest that clitic doubling in dialects (as described by Marušič and Žaucer 2009) requires some version of DP, as does so-called distant first conjunct agreement. Section 5 notes some possible problems. Section 6 offers some final reflections about how the APR and animacy "switch" might be formally implemented in Distributed Morphology terms and why this process targets pronouns in particular. 